University of Chicago Law School

Chicago Unbound

Journal Articles

Faculty Scholarship

1983

\title{
A Common Law for Labor Relations: A Critique of the New Deal Labor Legislation
}

Richard A. Epstein

Follow this and additional works at: https://chicagounbound.uchicago.edu/journal_articles

Part of the Law Commons

\section{Recommended Citation}

Richard A. Epstein, "A Common Law for Labor Relations: A Critique of the New Deal Labor Legislation," 92 Yale Law Journal 1357 (1983).

This Article is brought to you for free and open access by the Faculty Scholarship at Chicago Unbound. It has been accepted for inclusion in Journal Articles by an authorized administrator of Chicago Unbound. For more information, please contact unbound@law.uchicago.edu. 


\title{
The Yale Law Journal
}

Volume 92, Number 8, July 1983

\section{A Common Law for Labor Relations: A Critique of the New Deal Labor Legislation}

\author{
Richard A. Epstein†
}

During the nineteenth century, the area of labor relations was governed by a set of legal rules that spanned the law of property, contract, tort, and procedure. There was no special set of rules for labor cases as such. Since the advent of the New Deal, these common law principles have largely given way to a complex body of statutory and administrative law that treats labor law as a separate and self-contained subject. The central question in this paper is whether there is any warrant for the special treatment that labor law receives today. I shall concentrate upon the Norris-LaGuardia Act of 1932, ${ }^{1}$ and the Wagner Act of $1935,{ }^{2}$ the latter a New Deal statute and the former nearly so. My conclusion is that this (for ease of expression) New Deal legislation is in large measure a mistake that, if possible, should be scrapped in favor of the adoption of a sensible common law regime relying heavily upon tort and contract law. The tort principles protect all individuals against the use or threat of force, and-of great relevance here-against the deliberate inducement of breach of contract. The contract principles allow individuals within this

$\dagger$ James Parker Hall Professor of Law, University of Chicago. I would like to thank Dennis Carlton, Frank Easterbrook, Bernard Meltzer, and Cass Sunstein for their valuable comments on an earlier draft of this Article. Ross Green provided valuable research assistance. I have also benefited from the comments made both at the Yale Law Journal Symposium in February, 1983, and at a faculty workshop at the University of Michigan in April, 1983.

1. 18 U.S.C. $\S 3692,29$ U.S.C. $\S \S 101-115$ (1982).

2. 29 U.S.C. $\S \S 151-169$ (1982). 
social framework of entitlements to make whatever bargains they please with whomever they please.

At the outset it is important to note several important caveats about my analysis. In making these arguments I seek to analyze and evaluate labor law, not to construct a practical program or propose political reform. My operating premise is simple: No set of institutions should be exempt from serious criticism and review. The point is especially important in labor relations, where most modern legal scholarship is confined to the analysis of cases and practices within the current statutory framework. What is needed is an analysis of the statutory framework itself. Much of the critical writing on the subject dates from the 1930's and earlier, ${ }^{3}$ before the recent advances both in general legal theory and in law and economics. The fiftieth anniversary of the New Deal is an appropriate occasion for renewed critical scrutiny, as well as for celebration.

The outline of this paper is as follows. In the first section, I argue that common law rules provide an appropriate benchmark against which to measure the modern statutory developments. In the second section, I show how a coherent theory of private law, with well developed principles of contract and tort, can govern labor relations. Section III shows the substantial convergence of libertarian and utilitarian principles as they apply to labor relations. In Section IV, I shall look at the way in which the New Deal reforms handled the tort and contract issues, particularly the soundness of a statutory list of "unfair labor practices" of employers and of its system of exclusive collective bargaining. Section $V$ then examines and criticizes the broader justifications of industrial peace and industrial democracy used to justify the New Deal labor statutes. In dealing with the basic institutional structures, I shall look at both their inherent desirability and their dependence upon a large administrative apparatus. No constitutional questions are assayed. After the basic examination, I shall conclude with a brief discussion about the relationship between the New Deal legislation and the ends it seeks to advance.

\section{The Common Law Benchmark}

In conducting this investigation, one might ask, why look at common law rules? The answer is that traditional common law principles provide a benchmark, both theoretical and historical, against which the modern statutory schemes can be measured. The actual common law, however, is often highly unruly. Judges themselves often have profound disagreements

3. See, e.g., F. Frankfurter \& N. GreEne, The Labor InJunction (1930); Magruder, $A$ Half Century of Legal Influence Upon the Development of Collective Bargaining, 50 HARV. L. REV. 1071 (1937); Powell, Collective Bargaining Before the Supreme Court, 33 POL. SCI. Q. 396 (1918). 
as to the first premises in the legal debate, and in any event the number of decisions is simply too great to allow harmony to reign here, just as it is (a fortiori) with administrative actions pursuant to complex legislative schemes. In speaking of "the" common law, therefore, I am referring to the best set of private-law rules that can be devised to handle the problems of labor relations. The rules themselves, however, cannot be judged sufficient simply because they give the ideal responses suitable to an ideal world. To the contrary, these rules, like all others, must be judged as well by the way in which they handle problems of uncertainty, error, and enforcement.

As a substantive matter, the defense of a common law system is not an assertion that the "market" can handle every social problem. The law of property and the law of torts are strictly required in order to establish the framework of original rights in which voluntary transactions can take place. Nonetheless, the reference to common law solutions throughout this article does reflect a basic intellectual orientation in favor of limited government and the maximization of private autonomy. This premise is not, of course, an endorsement of anarchy. It accepts-indeed insists-that the state is entitled to prevent the private use of force and violence and to enforce promises, except when those promises are induced by duress or misrepresentation, or made by persons of manifest incompetence such as infants and insane persons. ${ }^{4}$

One virtue of this basic set of rules is that it is capable of sustained application. The qualifications of the basic principle (misrepresentation, duress, and incompetence) are not, as has been suggested, ${ }^{5}$ so infinitely expandable that they may be invoked almost as a matter of course to defeat every commercial or employment transaction, whenever either party has regrets after the fact. Misrepresentation may be expanded to cover cases of "a nod or a wink";, duress may include duress of goods;" and incompetence (or at least necessity) may reach bargains entered into by persons in imminent peril of their lives. ${ }^{8}$ But taken together, only a tiny percentage of transactions will be caught by these escape clauses, even recognizing their central role in the theoretical structure of contract. In

4. See Epstein, Unconscionability: A Critical Reappraisal, 18 J.L. \& ECON. 293 (1975), where I defend this basic position. Much of this paper is an extended application of that theory to labor relations.

5. Kennedy, Distributive and Paternalist Motives in Contract and Tort Law, With Special Reference to Compulsory Terms and Unequal Bargaining Power, 41 MD. L. REV. 563, 582 (1982).

6. Walters v. Morgan, 3 DeG. F. \& J. 718, 724, 45 Eng. Rep. 1056, 1059 (Ch. App. 1861 ).

7. Duress of goods includes cases in which a party who has promised to supply goods at a given price will do so only if some higher price is paid. See, e.g., Sistrom v. Anderson, 51 Cal. App. 2d 213, 124 P.2d 372 (1942). For discussions, see Dawson, Economic Duress-An Essay in Perspective, 45 MICH. L. REV. 253 (1947); Epstein, supra note 4.

8. See, e.g., Post v. Jones, 60 U.S. (19 How.) 150 (1857). 
any event, these grounds are generally inapposite in employment cases, a point tacitly conceded by the well-nigh universal insistence that such transactions should be set aside on a still broader ground-the "inequality of bargaining power." This principle, of course, is wholly incompatible with the liberal ideal that most contracts are for the mutual benefit of both sides, regardless of their original endowments of wealth. ${ }^{9}$

The strength of the common law's premises is also revealed by considering the alternatives. As a positive matter, Dean Verkuil is correct in noting that modern common law judges could develop rules for the contract of employment that are far worse than those created by the statute. ${ }^{10}$ But the criticism is wide of the mark in this context, as the question is whether it is possible to develop a competing normative view of the subject. The program of "substantive justice" in contracting, although oft proposed, is as far from realization today as it has ever been. ${ }^{11}$ Nor is that

9. Kennedy makes an effective critique of the usual arguments about standard form contracts, only to urge more fundamental measures to reshape the structure of American business institutions. See Kennedy, supra note 5, at 615-20.

More generally, one possible test of "inequality of bargaining power" asks us to imagine a perfect bilateral monopoly in which, for example, the issue was the division of $\$ 100$ between $A$ and $B$, where it was understood that neither party would get anything unless both agreed to the split. Inequality of bargaining power in this context refers to the situation in which one person is expected to receive more than $\$ 50$. Yet even if this account is viable, it is very difficult to imagine what set of workable institutions could restore the even split without upsetting the balance in the other direction. In any event, the best way to handle the problem is to undermine the institutional structures that perpetuate these rigid bilateral monopolies, as by facilitating freedom of entry into various markets. See infra p. 1396. (discussion of bilateral monopolies).

10. See Verkuil, Whose Common Law for Labor Relations? 92 Yale L.J. 1409 (1983).

11. The work of Zweigert and Kotz is representative of the dominant tradition:

We now realize that true freedom of contract cannot exist unless the parties to the contract are economically and socially equal.

Judge Pitney made this point brilliantly in Coppage v. Kansas, 236 U.S. 1, 17 (1915):

"It is impossible to uphold the freedom of contract and the right of private property without at the same time recognizing as legitimate those inequalities of fortune that are the necessary result of the exercise of those rights . . . . Indeed, a little reflection will show that whenever the right of private property and the right of free contract co-exist, each party, when contracting, is inevitably more or less influenced by the question whether he has much property or little or none: for the contract is made to the very end that each may gain something he needs or desires more urgently than that which he proposes to give in exchange."

Thus true freedom of contract could only operate in a Utopia, in a society in which businesses were independent, economically equal and fully automated, with neither labour nor management. If the parties are not socially and economically equal, only the stronger party is free to determine whether and how to form a contract. Such a society of equals does not exist anywhere, even in socialist countries, and probably never will, since it is a dream, freedom of contract in its pure form is itself a chimera, a fantasy and not in any way a reality. In the vast majority of the contracts which are concluded in modern society there is no freedom of contract, for the suppliers have fixed the conditions which the consumer can do nothing to alter. Freedom of contract exists only in contracts between large undertakings over atypical objects, and possibly in the area of labour law in the wage scale contracts produced by modern collective bargaining. Legal scholars must give up the habit of proclaiming that freedom of contract is a principle and then listing the exceptions to it. The main task is to discover criteria and procedures for the development of contractual justice, which the absence of freedom of contract makes it all the more necessary to promote. 
program supplied by an insistence that the public interest or "public values"12 forms an essential part of sound legal doctrine. Basically, this approach views regulation in all its aspects "to be not a matter of counting economic costs and benefits, or of defending private entitlements, but part of a continuing process of deciding what sort of a society we shall be."13 One problem with this approach is that it defines the scope of public values residually: Public values cover only that ground not incorporated by theories of individual entitlement or social production. Yet this theory cannot, in and of itself, establish where matters of private right end and matters of public dominance begin; the things which can count as public values are so wide and varied that virtually any manifestation of the collective legislative power is in principle sufficient to displace private rights. This public-interest view of legal doctrine is very different from the view of government that regards protection of private rights-of rich and poor alike-as the chief justification for the use of force. Likewise the public-interest view is very different from a system that permits in some instances the taking of private property upon payment of just compensation. The eminent-domain vision of the world abandons any idea that an original set of property rights is immutable within the social order. But it still insists that these original property rights be respected even if they are abrogated to advance the social good, by making the state pay for what it takes by force. ${ }^{14}$ By contrast, a public-interest view of the subject abandons any conception of private entitlements as its starting point, and thereby allows far greater latitude for government action.

To be sure, the common law theory developed here finds no place for the redistribution of wealth from rich to poor so characteristic of the modern state. Theories of redistribution are always difficult to construct: Welfare payments are never a matter of a legal entitlement of the recipients, but only an expression of collective benevolence by the transferors. ${ }^{15}$ No

The achievement of such contractual justice is no easy matter, and much further thought will have to be given to its answer.

2 K. ZWEIGERT \& H. KOTZ, AN INTRODUCTION TO COMPARATIVE LAW: THE INSTTTUTIONS OF PRIVATE LAW 8-9 (1977). The last sentence gives away the game. The entire passage is further flawed: It neglects the possibility that, even with economic inequality, the institution of contract still allows the weaker party to be left better off by the exchange.

12. Stewart \& Sunstein, Public Programs and Private Rights, 95 HaRv. L. Rev. 1195, 1238 (1982).

13. Id.

14. For an elaboration, see Epstein, Taxation, Regulation, Confiscation, 20 OSGoOdE HaLl L.J. 433 (1982).

15. The point is often lost sight of in the modern terminological shifts in the welfare area. Originally welfare payments were called "handouts" or the "dole," which inescapably captured the precarious position of the transferee. The word "welfare" tends to obscure the nature of the legal relation and to emphasize the end for which the payments are made. The modern emphasis upon "human services" (as in the shift from the Department of Health, Education and Welfare to the (reconstituted) Department of Health and Human Services) makes it appear that the payments are obligatory on the 
principle limits the power of a private party to choose who shall receive favors, and in what amounts; no private cause of action for want of benevolence forms the basis of the analogous public right, as does, for example, the law of nuisance for environmental protection. Private individuals find it difficult to identify who shall receive their bounty and to what extent. The problems are only compounded when these same matters are made the subject of collective decisions.

Nonetheless the indelible mark that the condition of the poor leaves on people of all political persuasions is enough to force any comprehensive theory of government to address the question. ${ }^{16}$ That examination could still conclude that compulsory redistribution is out of bounds as a matter of principle; if it did, it would strengthen the argument here by showing that there is no additional feature of the basic situation that could require a reexamination of the positions taken thus far. The critique of current labor laws stands, however, even if redistribution from rich to poor is accepted: There is no solid moral case for treating union members, as such, as the favored class of wealth redistribution. To make union members wealthier is to make poorer not only employers (whose shareholders are often workers whose pension funds have been invested in the corporation) but also the nonunion workforce and the poorer members of the general population. Redistributions from rich to poor have far greater appeal than redistributions, for example, from a nonunionized worker to a unionized worker of initially comparable economic status. Desired redistributions (if any) are best accomplished by general tax measures. The possibility of factional or class legislation is thereby reduced, as is the likelihood that the process of redistribution itself will hamper the creation of wealth. $^{17}$

transferor.

16. One commentator has asserted:

My point is rather that this principle-that basic material needs be guaranteed by government to those who cannot meet them through their own efforts-has come to have an entrenched status as one of the fixed moral imperatives governing our political life . . . . No working American politician would, for instance, advocate the libertarian doctrine advanced in Anarchy, State, and Utopia, with its principled rejection of all income security programs. Our Reagans and Goldwaters argue that there is waste and fraud in our welfare programs, that people are receiving welfare who should support themselves, that benefit levels are too high. Those all are arguments within the terms of the principle of basic needs as I have stated it, and presuppose acceptance of the principle itself.

Grey, Property and Need: The Welfare State and Theories of Distributive Justice, 28 STAN. L. REV. 877, 901 (1976) [hereinafter cited as Property and Need]; see also Grey, The First Virtue (Book Review), 25 STAN. L. REV. 286, 323-25 (1973).

17. The difference between special labor legislation and general taxation best explain the constitutional response of the Supreme Court to various forms of social legislation in the period before the New Deal. The Court struck down, on constitutional grounds, both federal and state statutes prohibiting yellow dog contracts in employment. See Adair v. United States, 208 U.S. 161 (1908) (federal); Coppage v. Kansas, 236 U.S. 1 (1915) (state). Yet at the same time the Court allowed, without so much as a note of protest, forms of taxation which did have, and were intended to have, general 
The weakness of overt redistributive arguments in the labor context is further revealed by the rhetoric used to justify both the Norris-LaGuardia and the Wagner Acts. While income redistribution to union employees from (amongst others) their employers was one apparent consequence of both these statutes, their passage was not overtly justified in these terms. Instead, it was said that the statutes were not designed to repudiate the market or to confiscate employer wealth. The statutes were said to be designed to cure the present system of its imperfections, if only to save capitalism from its own excesses. It seems therefore appropriate to put aside the question of income distribution as such, and to ask how any system of labor relations can be squared with a sound theory of individual entitlements and their social protection.

One further element is put aside in this analysis-the particular conditions of labor unrest both in the 1930's and before. It is often said that the massive social and economic dislocations of the Depression made it quite impossible to rest content with incremental adjustments to common law doctrine. ${ }^{18}$ Many New Deal reforms perished during and after the Depression, however, ${ }^{18}$ and there is no reason to hold modern labor law sacrosanct because it gained its maturity in the 1930's. Indeed, a sense of quiet desperation may well have led to the passage of labor statutes which in calmer times would have been rejected as destructive of both personal liberty and economic wealth for both society as a whole and most (but never all) individuals within it.

redistributive consequences. See, e.g., Brushaber v. Union Pac. R.R., 240 U.S. 1 (1916) (rejecting challenges to a progressive income tax while upholding the 1913 federal income tax law); Knowlton v. Moore, 178 U.S. 41 (1900) (upholding the federal inheritance tax); Magoun v. Illinois Trust \& Sav. Bank, 170 U.S. 283 (1898) (upholding the Illinois inheritance tax). See generally Blum \& Kalven, The Uncasy Case for Progressive Taxation, 19 U. CHI. L. REV. 417, 424 n.21 (1952) ("The cases are not helpful on the merits of the principle of progression.").

18. For judicial expression of the sentiment, see Home Bldg. \& Loan Ass'n v. Blaisdell, 290 U.S. $398,442-48$ (1934) (referring to emergency conditions that justified state mortgage moratoria against contract clause challenges).

The connection between social dislocations and labor law is a very different question, as no coherent theory links the common law of labor relations (unlike, for example, the management of the money supply) with bringing on the Depression, or shows that the legislation produced in the Depression contributed in any sensible way to economic recovery. There is certainly no explanation of why the common law of labor relations should be charged with the problems of the 1930's instead of being credited with the economic successes of earlier and better times.

19. See, e.g., United States v. Butler, 297 U.S. 1 (1936) (striking down Agricultural Adjustment Act); Schechter Poultry Corp. v. United States, 295 U.S. 495 (1935) (striking down $\S 3$ of National Industrial Recovery Act). Note too, that some programs have passed political muster, as with the deregulation of the airline industry, see Levine, Revisionism Revised? Airline Deregulation and Public Interest, 44 LAW \& CONTEMP. PROBS. 179 (1981). 


\section{The Common Law of Labor Organization}

In turning to our normative account of labor relations, it is proper to stress that common law rules in their ideal form make legal entitlements among strangers without reference to personal status. Legal rules do not refer to flesh-and-blood individuals, but to those lifeless abstractions, $A$ and $B$, about whom nothing else is known or-more to the point-is relevant. It may well be that certain individuals will in the end assume certain well-specified roles, but if so there is no reason to have legal institutions either subsidize or penalize their efforts: Individuals should not have to sacrifice their rights against the rest of the world because they become an employer of $A$ or an employee of $B$. Stating propositions in general form is, moreover, a powerful antidote to abuse and favoritism, even if standing alone it cannot guarantee a just set of rules or outcomes. ${ }^{20}$ To use Rawls' popular phrase, generalizations place people behind the veil of ignorance, depriving them of the knowledge of whether their application will help or hurt themselves or their friends. ${ }^{21}$ What, we ask, might these general rules look like in the context of labor organization?

We must begin with the original position: What are the rights and duties between strangers? We start first with the account offered under a theory of individual liberty, which can then be qualified by considerations of overall utility. ${ }^{22}$ Here the common law (except for its unfortunate early flirtation with the law of criminal conspiracy) ${ }^{23}$ took the sound position: ${ }^{24}$ Every person owns his own person and can possess, use and dispose of his labor on whatever terms he sees fit. ${ }^{25}$ To state otherwise is to say either

20. On the importance of generalization as protection against class intrigue, see Epstein, The Social Consequences of Common Law Rules, 95 HARV. L. REV. 1717 (1982).

21. See J. RAWLS, A THEORY OF JUSTICE 136-42 (1971).

22. For my own views on how these two areas might be reconciled, see Epstein, Nuisance Law: Corrective Justice and its Utilitarian Constraints, 8 J. LEGAL STUD. 49 (1979); Epstein, Private Property and the Public Domain: The Case of Antitrust, 24 NomOs 48 (1982) thereinafter cited as Private Property and the Public Domain].

23. See, e.g., Commonwealth v. Pullis (Phila. Mayor's Ct. 1806) (the Philadelphia Cordwainer's case), reprinted in $3 \mathrm{~J}$. COMMONS \& E. GILMORE, A DOCUMENTARY HISTORY OF AMERICAN INDUS. TRIAL SOCIETY 59-248 (1958). The turning point is often taken to be Shaw's opinion in Commonwealth v. Hunt, 45 Mass. (4 Met.) 111 (1842), but there were occasional strong anti-union sentiments thereafter. See, e.g., State v. Donaldson, 32 N.J.L. 151 (Sup. Ct. 1867) (indictable conspiracy exists when several employees combine and notify their employer that unless he discharges certain enumerated persons, they will quit in a body).

24. See Witte, Early American Labor Cases, 35 YALE L.J. 825 (1926). Witte's central conclusion was as follows:

It was never the law in the United States that labor unions are illegal per se, or that all strikes are unlawful. The unreported cases of the early nineteenth century did not turn upon the legality of the unions per se, but on the methods which they employed to gain their ends. Nor were the views expressed in these early cases as to the methods which might lawfully be employed less liberal than those now generally held by the courts. Id. at $825-26$.

25.

Every person has a right under the law, as between him and his fellow subjects, to full 
that the labor cannot be used or that someone else is entitled to direct its use. At the same time, the common law position also blocks off the institution of slavery-a constant theme in the debates over labor legislation ${ }^{28}$-at the outset.

Of the three rights in the original ownership bundle, ambiguity in the labor context attaches only to the right of disposition. In this context it could mean that a person has a right to dispose of his labor on his own terms, so that if $I$ wished to dispose of my labor for $\$ 10$ per hour, some other person would be required to acquire it at that price. Such a system of rights cannot be applied to all individuals, however, ${ }^{27}$ for it would allow me to deny others the very liberties that I claim for myself: What could I say if someone wanted me to hire him for $\$ 1000$ per hour? To be universal in application, the right of disposition must be understood to include only the right to offer one's services on whatever terms and conditions one sees fit. In good Hobbesian fashion, the appetite of every person determines the appropriate terms of exchange. The system can now specify the correlative obligations of the right to offer one's labor unhindered-without interference by force or fraud-which can be held simultaneously by all individuals. ${ }^{28}$

Over time, the original distribution of wealth is likely to change as labor is exchanged for labor or for capital. Within the liberty-based framework, no limitation is placed upon the voluntary recombination of entitle-

\footnotetext{
freedom in disposing of his own labor or his own capital according to his own will. It follows that every other person is subject to the correlative duty arising therefrom, and is prohibited from any obstruction to the fullest exercise of this right which can be made compatible with the exercise of similar rights by others. Every act causing an obstruction to another in the exercise of the right comprised within this description-done, not in the exercise of the actor's own right, but for the purpose of obstruction-would, if damage should be caused thereby to the party obstructed, be a violation of this prohibition ....
}

W. ERLE, THE LAW Relating to TRADE UNIONS 12 (1869) (emphasis deleted). The passage is clearly correct when it notes that the articulation of the basic right is incomplete without the specification of the correlative duty. But it nowhere indicates why the "purpose of the obstruction" should be decisive instead of the means used to achieve it. And it hardly suffices to include a statement of the "actor's own right" in a description of the correlative duties.

26. The theme of the "wage slave" is evident enough in political theory. The provisions of the Clayton Act which stipulate that labor should not be regarded as an article of commerce also reflect that view. See Clayton Act, § 6, 15 U.S.C. § 17 (1982).

27. For an extended treatment of this theme, see Epstein, Intentional Harms, 4 J. LEGAL STUD. 391, 425-27 (1975).

28. The constraints upon a generalized system of entitlements reveal the intrinsic weakness of the view, advanced by Grey among many others, that all individuals are entitled to receive some minimum standard of support when they are unable to support themselves. See Property and Need, supra note 16, at 897-901. This standard must define the minimum level of support, and show how the system itself can generate sufficient wealth to meet its minimum obligations. It must also explain which individuals bear the correlative duties necessary to furnish the wealth in question. I am skeptical that these tasks can be discharged in a persuasive way, but for these purposes the central point is that this conception of entitlement is of no use in labor cases, where the redistributions will almost always be capricious, whatever its critical relevance to the question of welfare legislation. 
ments by their holders, original or derivative. ${ }^{29}$ Any set of moves is as good as another, so long as the moves themselves do not violate the rights of third parties and do not involve the use of prohibited means between competent parties. Becoming an employer or an employee is strictly a private act in which one person decides to offer his own capital in exchange for the services of another individual, or vice versa, on whatever terms the parties to the exchange see fit. The parties' decision to enter into a contractual agreement does not increase or decrease the sum of rights that they have against the rest of the world, or that the rest of the world has against them. The creation of voluntary arrangements is therefore never an occasion for increased state regulation of private transactions apart from the faithful enforcement of their agreement, be it in employment relations or anything else.

As the identities of the contracting parties and the terms on which they contract are of no special concern to the state, a contract between an employer and an employee is indistinguishable from one between two prospective employees. The protection of labor unions from doctrines of criminal conspiracy, therefore, should not depend upon any elaborate affirmative social justification for their use. If $A$ could enter into a contract with a prospective employer, then there is no reason he cannot enter into a contract with his potential rival, $B$, to present a united front against the employer. ${ }^{30}$ Similarly, the voluntary formation of labor unions need involve neither the use of force and fraud nor the inducement of breach of contract. There is therefore no need to appeal to special justification to account for the legality of labor unions, as it is already accounted for by a general theory of entitlements. To be sure, there are profound differences in the worth of the original set of endowments held by individuals (and by the firms or organizations that they create), but these have only descriptive significance in predicting what moves the parties will make within the rules. The refusal (or inability) to predict which arrangements will emerge in no way amounts to a defect of the theory. Prediction is within the province of economics and sociology. The function of a system of enti-

29. The position was well enunciated in the classical statement of libertarian principles in Coppage v. Kansas, 236 U.S. 1, 17 (1915). Coppage was, however, overruled sub silentio in Virginian Ry. v. System Fed'n No. 40, 300 U.S. 515 (1937), and expressly in Phelps Dodge Corp. v. NLRB, 313 U.S. 177, 187 (1941). The approach of Coppage has found modern philosophical support in $\mathbf{R}$. NOZICK, ANARCHY, STATE, AND UTOPIA (1974).

30. The parallel between antitrust law and labor law is evident: There is no autonomy-based theory that accounts for antitrust law as applied to industry or for antitrust law as applied to labor law. I have explored this point in greater detail in Private Property and the Public Domain, supra note 22. The late nineteenth-century cases on economic harms show the close relationship between the two problems by treating both antitrust and labor cases within a single framework. See, e.g., Mogul S.S. Co. v. McGregor Gow, \& Co., [1889] 23 Q.B.D. 598, aff'd, 1892 A.C. 25; Allen v. Flood, 1898 A.C. 1; Quinn v. Leathem, 1901 A.C. 495; see also Mayor of Bradford v. Pickles, 1895 A.C. 587 (same analysis applied to nuisance cases). 
tlements is only to determine after the fact whether the patterns that have emerged fall within the proper rules of the game. The law of contracts is no more designed to predict the terms contained in particular contracts than the rules of chess are designed to determine the soundness of the Ruy Lopez.

The strength of the theory is revealed by its treatment of three recurrent problems in the law of labor relations. The first problem is the role of "malice" and combination in labor disputes; the second concerns the place of the so-called "yellow dog" contract in employment relationships; and the last is the question of picketing.

\section{A. Malice and combination}

Malice and combination were at the heart of the great labor cases of the late nineteenth century in both England and the United States. One position, chiefly associated with the majority view in Allen v. Flood, ${ }^{31}$ treated both malice and combination as wholly immaterial to the question of liability. When, therefore, one group of workers announced through their union leaders that they would not continue in the employ of a third party unless he dismissed the members of a rival union working under contracts at will, this conduct was held in Allen not to be tortious, even if actuated by malice. ${ }^{32}$ The majority relied heavily on its earlier decision in Mogul $v$. McGregor, ${ }^{33}$ which held that a combination of shippers could act to exclude rivals by predatory pricing even though their intention was to inflict economic harm in order to secure their own self-advancement.

Three years later, however, the House of Lords adopted a very different view of labor disputes in Quinn v. Leathem, ${ }^{34}$ holding that a second-

31. For an interpretation of Allen v. Flood that stresses the factual argument that Allen was no more than a messenger for the iron-men in his union who did not induce the dismissal at all, see Petro, Unions and the Southern Courts: Part III-The Conspiracy and Tort Foundations of the Labor Injunction, 60 N.C.L. REV. 543, 558-67 (1982). Support for his view of the facts is found, for example, in the careful opinion of Lord Macnaghten, 1898 A.C. at 143-150. But Macnaghten also said: "Even if I am wrong in my view of the evidence and the verdict, if the verdict amounts to a finding that Allen's conduct was malicious in every sense of the word, and that he procured the dismissal of Flood and Taylor, that is, that it was his act and conduct alone which caused their dismissal, . . . I should still be of the opinion that judgment was wrongly entered for the respondents." Id. at 151. In addition, his view was sharply contested in other opinions, including that of Lord Morris, which found that Allen "proceeded to threaten the employers with the withdrawal of the boilermakers which would be most injurious to the employers, unless the plaintiffs were dismissed at once." Id. at 159. In any event, it is only on the point of principle-the rule of malice-that the case has any theoretical interest. It is quite incomprehensible why it should attract any attention if it turned on a simple question of fact. Note that Lord Herschell concluded his long opinion by saying "that I regard the decision under appeal as one absolutely novel, and which can only be supported by affirming propositions far-reaching in their consequences and in my opinion dangerous and unsound." Id. at 143.

32. 1898 A.C. at 1.

33. 23 Q.B.D. 598 (1889), aff'd, 1892 A.C. 25.

34. 1901 A.C. 495. 
ary boycott by a labor union, which sought both to unionize the defendant's shop and to replace his current employees with union members, was actionable, given the conspiracy of the union members and their asserted malice toward the plaintiff. The decision has been rightly attacked as wholly inconsistent with the general principles of Allen, which itself could be transformed easily into a conspiracy case given that the defendant Allen represented a union, all of whose members were prepared to strike over the work issue. ${ }^{35}$ In addition, Quinn seems difficult to reconcile with Mogul given that the union's actions were well calculated to serve the self-interest of its members, both by placing current members in high paying jobs and by choking off the powerful economic competition from nonunion shops.

The irreconcilable differences amongst these three English cases is warning enough of the difficulty of maintaining a harmonious set of common law rules. It should not be surprising therefore that these same doctrinal conflicts manifested themselves in the American cases, which in this particular instance rested very heavily upon the English decisions. Plant $v$. Wood, ${ }^{36}$ strongly reminiscent of Quinn, held that liability turned on matters of intent when employees acted in concert-in this case, an effort to force nonunion workers to join a union shop. ${ }^{37}$ The court in Plant took the general, if vague, position that workers who combined together to injure another engaged in wrongful conduct, whereas those who combined together to benefit themselves did not. The determination as to which ends were consonant with "legitimate" self-interest required courts to develop shadowy and unsatisfactory ways to distinguish between different brands of egoism: Should there be one response where the collective refusal to deal was intended to force other workers to join the striking union, and another where the goal was higher wages for union members? Plant and Quinn are clearly less consistent with a liberty-based theory than is Allen. That they impose greater restrictions upon labor unions is quite beside the point.

A closer analysis of the legal conception of malice helps clarify the proper rules of union liability. Malice in its pure form means more than an intention to inflict some temporal injury. All competition, and most economic activity, will do that. Instead it refers to actions done out of spite or ill will, whereby someone is prepared to impose costs upon himself solely to make someone else worse off. So defined, malice does not offer a viable route to either survival or advancement; indeed it is negated by the

35. See G. GREGORY, LABOR AND THE LAW 46-51 (2d ed. 1958).

36. 176 Mass. 492, 57 N.E. 1011 (1900).

37. Id. For a contrast to the majority view of Plant, see National Protective Ass'n v. Cumming, 170 N.Y. 315, 63 N.E. 369 (1902), which followed the argument of Holmes' classic dissent in Plant. 
economic self-interest found in both Quinn and Plant. Any prohibition against malicious conduct, therefore, at most reaches only the fringes of individual and union behavior. Allen neatly avoids the problem of inquiring into motives for collective action entirely. But, by fastening exclusively on the means used, Allen did not reduce the law to conclusionary assertions about lawful and unlawful acts.

Under Allen, however, it is possible to supply an independent account of what constitutes unlawful means: force, fraud, and inducement of breach of contract. As long as workers, either alone or in combination, do no more than withhold or threaten to withhold labor that they are not bound by contract to supply, they have not trenched upon the rights of the rival workers, even if rival workers suffer as a consequence. The thirdparty employer could resist the demands of the defendants and continue to employ the plaintiffs, as did the employer in Quinn. Alternatively, the plaintiffs could agree to reduced wages or to different work in order to keep their previous positions. The targeted employer may even capitulate to the demands of the rival union. The autonomy-based theory does not predict outcome, but accepts whichever outcome emerges as the voluntary recombination of entitlements within the framework of the tort law. ${ }^{38}$

Unless, therefore, one wants to take the position that unions by their nature must engage in such illegal acts, they and a wide range of their activities remain protected under a strong theory of entitlements that contains not a whisper of special status or privilege. Labor unions should not be considered criminal conspiracies not because they do not operate in restraint of trade-many do-but because restraint of trade itself should not be illegal. The vacillation between Allen and Quinn has been attacked as a double standard of the private law-with harsher rules for labor than for business. ${ }^{39}$ Whether this overall condemnation is justified is an open question. What is beyond dispute is the proposition that (at least in the libertarian view) legislation that secures the rules of Allen is appropriate, even if more massive labor legislation is not.

38. It remains true that if malice and combination are found in cases in which there is the threat or use of force, or an inducement of contractual breach, matters are worsened by the combination. Mobs are more dangerous than isolated individuals. But even here the important point is as before: The nature of the conduct must first be shown to be a violation of right before questions of motive and combination can be introduced by way of aggravation. The matter became quite cloudy in English law. Sec, e.g., Crofter Hand Woven Harris Tweed Co. v. Veitch, 1942 A.C. 435; Sorrell v. Smith, 1925 A.C. 700. For discussion, see W. ROGERS, WINFIELD \& JOLOWICZ ON TORT 461-67 (10th ed. 1975).

39. See C. GREGORY, supra, note 35, at 46-51. Note that the equivocation on the central point in both the American and the English cases makes it very difficult to draw any clear inferences of judicial bias from the legal decisions. If the judges had been so biased in the first instance, there would be no way to explain Allen. 


\section{B. Yellow Dog Contracts}

The strong theories of individual entitlement applicable to labor unions apply with equal force to the "yellow dog" contract. In such contracts, a worker agrees as a condition of employment that he will not become a member of a labor organization. These contracts are today forbidden by explicit statutory command ${ }^{40}$ and have been uniformly condemned by academic writers as being self-evidently unjust-even, as Calvert Magruder said, a "curse." 11 Their status as a matter of strict autonomy-based theory is, however, quite different: They should be accorded the same respect as any other voluntary agreement. Thus, in order to invalidate such an arrangement, one must show that it involves the use or the threat of force against a third party. To the extent that it requires only that a worker steer clear of unions in order to obtain or keep a job it does nothing of the sort. ${ }^{22}$ To be sure, the yellow dog contract is improper if it requires an individual worker to breach a membership contract with his union. If the current statutory prohibition were directed only to that situation, it would be fully justified as a protection of vested rights. But no one thinks that the problem with yellow dog contracts is inducement of breach of intraunion contracts by employers. The opposition always takes the position that the yellow dog contract is against public policy in all its manifestations. ${ }^{43}$ The support for the prohibition came from labor unions, its chief beneficiaries, who wanted to overcome any obstacles to unionization these contracts posed. Yet no attention was paid to the mode of that frustration, which by the general theory of entitlements is the one question that matters. ${ }^{44}$

In defense of the current prohibition of the yellow dog contract it is sometimes said that "[ $[$ ] he Norris-LaGuardia Act introduced the only per-

40. National Labor Relations Act, 29 U.S.C. § 158(a)(3) (1982).

41. Magruder, supra note 3 , at 1083 . The relevant passage reads as follows:

The Adair case was carried further in Coppage v. Kansas, where by a six-to-three vote the Supreme Court held invalid under the Fourteenth Amendment a state statute making it criminal for an employer to exact a yellow dog contract as a condition of employment. The curse has finally been taken from these cases by the recent decision upholding the National Labor Relations Act.

It seems an easy inference (especially from the tenor of the paper) to assume that Adair and Coppage were curses because the yellow dog contract was a curse. No argument is offered, however, to explain its social evil.

For similar sentiments, see A. COX, LAW AND THE NATIONAL LABOR POLICY (1960), where it is assumed that the errors in Hitchman are self-evident: "Decisions like the Hitchman case seemed to display either prejudice or a lack of elementary economics." Id. at 7. The only economic analysis offered here, however, consists of a theoretical and inaccurate assertion urging: "The Hitchman injunction thwarted the United Mine Workers but did not improve the lot of the coal miners." Id.

42. Justice Brandeis took the view that coercion should be very narrowly defined in labor cases. Hitchman Coal \& Coke Co. v. Mitchell, 245 U.S. 229, 271-72 (1917) (Brandeis, J., dissenting).

43. F. FRANKfURTER \& N. GREENE, supra note 3; A. CoX, supra note 41.

44. A. CoX, supra note 41 , at 8 . 
iod of unqualified laissez faire in labor relations." ${ }^{35}$ But the proposition is based upon a misapprehension of what laissez faire demands of government. To be sure, the Norris-LaGuardia Act (like the Wagner Act) did not involve government dictation of the terms and conditions of individual or collective agreements. ${ }^{48}$ Yet the insistence, as revealed in the NorrisLaGuardia Act's exhortation, that workers obtain "acceptable terms and conditions of employment," ${ }^{\mathbf{4} 7}$ hardly speaks to the process of contractual formation, much less to the glory of "the competitive struggle of life," that is central to the theory of laissez faire. To the contrary, the statute looks to the outcome of the process and demands a theory of just dessert that is incompatible with laissez faire principles.

Nor does the absence of any administrative structure convert the Norris-LaGuardia Act into a safeguard for laissez faire principles. For laissez faire, the ultimate question is not whether, given the established legal framework, the parties are entitled to bargain to whatever terms and conditions they see fit. It is whether the legal constraints within which the negotiation takes place are consistent with a rigorous theory of individual entitlements. Individuals can bargain with kidnappers without the benefit of state mediation on the amount of the ransom needed to secure release, but the prior question is, by what warrant must a person purchase the release of another individual when that individual ought already to be free as a matter of right? If we have learned anything from the law of the duress of goods, ${ }^{\mathbf{4}}$ it is that the existence of choice, without more, is not a sufficient condition for contractual freedom. The issue remains one of entitlements: Is the choice between something one owns and something one wants, or is it between two things one owns? In the former context we can speak of bargains worthy of respect. In the latter, by analogy to duress of goods, we can speak only of bargains under coercion.

These insights apply with undiminished force to the labor context. Why limit freedom of contract between employer and employee? It is often said that choices left to the worker under the common law are "illusory," in that without statutory protection the worker has no choice but to succumb

45. Id.

46. "The basic theory of the law [i.e., the Wagner Act] in its original form, as today, was that the arrangement of the substantive terms and conditions of employment is a private responsibility." Id. at 11. The position is endorsed in many judicial decisions. See, e.g., H.K. Porter Co. v. NLRB, 397 U.S. 99 (1970). There is no question that the government is well advised to stay out of these matters. But it is quite a different proposition to treat massive structural interferences with voluntary transactions as though there were no interferences at all.

47. 29 U.S.C. $\S 102$ (1982). The section also refers to the workers' right of "full freedom of association" as a justification for the limitation of the yellow dog contract, but does not address the question of how the statutory prohibition preserves the similar "full freedom of association" for both employers and workers who wish to sign yellow dog agreements.

48. See supra note 7. 
to the employer's pressure. One factual objection to the theory is that it can neither account for the fact that the workers received positive wages for their employment before the adoption of the modern labor legislation, nor for the equally obvious fact that there were wage differentials between workers in different trades and with different skills. If inequality of bargaining power had any descriptive power as a model, then why did employers not use their power to reduce wages to the vanishing point, or refuse to accept unionization before the passage of either the NorrisLaGuardia or Wagner Acts? As a matter of principle, the liberal theory of contract draws a very powerful distinction between the duress which is imposed by the threat of force by one party against the other, and the duress, so-called, attributable to economic and personal pressures to which all parties are subjected by the inevitable considerations of scarcity. To adopt the modern language of "unconscionability," 40 it is a meaningful choice to refuse employment altogether; no one would count it the loss of a meaningless choice if employers were given the right to conscript employees into service. To insist, therefore, that there be economic equality before there can be contract is to destroy the usefulness of contract by imposing a set of exacting conditions that can never be satisfied or even approached. To confuse economic inequality with duress is to say that no bargains are ever free from duress, and to swallow up freedom of contract by an unprincipled expansion of the principled limitations upon the basic rule. It is quite enough that the contracts leave the parties better off than they were before. It is too much to ask of any system of rules that it correct whatever asserted social imbalances exist before the contract formation.

The weakness of the arguments of economic duress can be demonstrated in yet another fashion. It is not coercive for a party to choose not to go into business at all, even though that exercise of rights reduces the options available to any prospective employee. It cannot therefore be an abuse to increase the options available to any person by giving him an opportunity to work that he cannot claim as of right and, in fact, would not have otherwise. A yellow dog agreement could be coercive only if prospective employees had a precontractual right to demand both union membership and employment. But it is unclear how any principled account of individual rights could generate that set of uneven entitlements. So long as the worker owns his labor, and the employer his capital, then the liberal theory of contract is neutral with respect both to the identity of contracting parties and to the terms of the agreement. No law prohibits two business partners from demanding exclusive loyalty from each other, nor

49. Williams v. Walker-Thomas Furniture Co., 350 F.2d 445, 449-50 (D.C. Cir. 1965). 
is there any reason why such loyalty cannot be demanded of an employee by his employer, or of an employer by the employee (as in the promise not to hire nonunion labor). The Norris-LaGuardia Act can be regarded as compatible with laissez faire only if the sole permissible sequence of agreements dictates that agreements among workers precede those between workers in combination with employers. This is no more sensible than saying that sound industrial policy demands that cartelization amongst sellers should necessarily precede sales to customers.

In principle, there remains one other way to argue that public policy should prohibit the yellow dog contract. That is to show that the contracts themselves are of necessity entered into by processes (to wit, force and fraud) that themselves negate any true consent. There is a clear hint of this theme in the language of the Norris-LaGuardia Act, which states without elaboration that "the individual unorganized worker is commonly helpless to exercise actual liberty of contract and to protect his freedom of labor, and thereby to obtain acceptable terms and conditions of employment." ${ }^{30}$ The source of the helplessness is left unspecified, but there is no indication that it is anything more than the difference between the two sides, command over resources, itself a factor immaterial to an entitlement theory of contract. And it is surely odd that a yellow dog contract should not count as an exercise in liberty of contract as much as a decision to cast one's lot with other workers.

The theory of laissez faire, then, is unambiguous in its support of the legality of the yellow dog contract. This was recognized by the believers in constitutionally based laissez faire when they struck down statutory prohibitions against the arrangements in Adair v. United States. ${ }^{51}$ The strength of Adair's conclusion is further supported by an examination of Hitchman Coal \& Coke Co. v. Mitchell, ${ }^{\mathbf{6} 2}$ the key case upholding the legality of the yellow dog contract in the pre-New Deal era.

In Hitchman, the plaintiff coal mine had struggled through a protracted dispute with the United Mine Workers. On several occasions, management agreed to accept a closed union shop, but the arrangements always collapsed when up for renewal, producing a series of strikes that depleted the resources of both the firm and the union. During one of these strikes, several miners came to the employer offering to work on a nonunion basis for the prevailing union wages. It was agreed that the company would no longer recognize the United Mine Workers, and that no employee of the

50. 29 U.S.C. $\S 102(1982)$.

51. 208 U.S. 161 (1908). Holmes' dissent, id. at 190, went not so much to the status of the agreement under the general common law theory, but to the separate and difficult question of the extent to which that theory has been incorporated into the Constitution. Id. at 191.

52. 245 U.S. 229 (1917). 
firm could be a member of the union. These were contracts at will, so the workers were free to leave the employ of the company at any time and join the union. The agreement in question was accepted by all employees of the mine. Representatives of the United Mine Workers later attempted to secure workers' promises to go out on strike as members of the union when requested to do so. The organizers did not use force or misrepresentation against the employees to achieve their goals. The organizers did, however, request employees who agreed to join the union to remain on their jobs, fearing that the company could easily secure replacements if dissatisfied workers left on a gradual basis. When the company discovered the activities of the key union personnel, it sought to enjoin those activities on the ground that they constituted an inducement of breach of contract. In an analysis consistent with the general liberal theory of contract developed here, the Supreme Court held that the injunction was warranted, although overbroad in some of its particulars. There was no question that the contract of employment was valid as between the parties. As the arrangement was at will, the company could have dismissed individual workers on the spot if it discovered their affiliation with the union. More to the point, it could have argued that the employees were in breach of a material condition and therefore could have made a powerful claim to withhold (or perhaps recover) the wages paid to the workers during the period of their union affiliation. These conclusions could not be upset on the ground that the contract infringed the rights of third persons to be free, among other things, from force and fraud.

The only way to argue against an injunction was therefore to show that the tort of inducement of breach of contract did not apply to ordinary labor disputes. Lumley v. Gye, ${ }^{53}$ the basic decision in the area, had granted the plaintiff impresario an injunction against a defendant who had knowingly induced a famous opera singer to breach her contract with the plaintiff. Thereafter, both the English and American courts extended Lumley to ordinary labor contracts, finding the use of the injunction uncontroversial..$^{54}$

The application of Lumley to Hitchman is clear enough. So long as the current contract had any positive value to the promisee, the tort action is appropriate. As it was clear to all concerned that covert union membership (aside from being a fraud against the employer) weakened the employer's economic position against the employee, the common law tort applied to the case in a perfectly straightforward manner. The only question that remained was whether an injunction against the third party provided

53. 2 E. \& B. 216,118 Eng. Rep. 749 (1853).

54. See Walker v. Cronin, 107 Mass. 555 (1871); Bowen v. Hall, 6 Q.B.D. 333 (1881). 
the proper remedy. Here the ongoing commission of the tort and the difficulty in estimating the damages that could flow from a sudden disruption of services brought about by a strike make such a remedy proper under the ordinary equitable principles governing injunctions.

In its own way, Brandeis's dissent is even more instructive than Pitney's admirable majority opinion. Brandeis utters not a single word against the common law conceptual framework that Justice Pitney used to analyze the case. The crux of Brandeis's argument follows:

The contract created an employment at will: and the employee was free to leave at any time. The contract did not bind the employee not to join the union; and he was free to join it at any time. The contract merely bound him to withdraw from plaintiff's employ, if he joined the union. There is evidence of an attempt to induce plaintiff's employees to agree to join the union; but none whatever of any attempt to induce them to violate their contract. Until an employee actually joined the union he was not, under the contract, called upon to leave the plaintiff's employ. There consequently would be no breach of contract until the employee both joined the union and failed to withdraw from plaintiff's employ. ${ }^{\circ 5}$

At best this is an argument only of contract construction, and a very bad argument at that. As Pitney points out, ${ }^{56}$ there is nothing of substance to distinguish joining the union from agreeing to join the union at some future time. The arrangement between the employer and the workers was that the workers' sole loyalty was to the employer. There is no question that dual and inconsistent loyalties are created even if a worker takes the neat precaution of not signing a membership card while remaining on the job at the behest of the union. If this had been a case in which one impresario had bid for the services of an opera star already under contract to a rival, a demonstration of the breach and its inducement would have been trivial matters. Pitney was clearly correct in observing that, as courts of equity had long looked "to the substance and essence of things and disregarded matters of form and technical nicety, it is sufficient to say that to induce men to agree to join is but a mode of inducing them to join. . . ."5r

\section{Picketing}

It remains here only to consider the proper treatment of picketing within the libertarian framework. Here the point of departure is that the prohibition against the use of force reaches the threat of force. If killing is

55. 245 U.S. at 272 .

56. Id. at 255 (italics in original).

57. Id. 
illegal, then so too must be armed robbery, even if the gun is not fired. Wholly apart from the labor context, there has never been a difficulty in accepting the general proposition. But what are the limits of the rule? Blackstone's definition of assault was restrictive: It included an "attempt or offer to beat another, without touching him; as if one lifts up his cane, or his fist in a threatening manner at another." ${ }^{138}$ Under this account the defendant must have both the capability and the immediate opportunity to inflict the harm in question, an overly restrictive view of liability, even for a common lawyer. Today the general view is that an action lies "when it is shown that one, in the absence of any privilege, intentionally subjects another to the mental suffering incident to serious threats to his physical well-being, whether or not the threats are made under such circumstances as to constitute a technical assault." ${ }^{\text {"59 }}$ The creation of, as it were, an action on the case for an indirect assault lengthens the causal chain and complicates the manner of proof, but these difficulties do not preclude liability on theoretical grounds.

For our purposes the general rules of assault form the framework with which to analyze picketing. The first inquiry is whether "picketing" constitutes a threat of force against persons who cross the picket line. The question is difficult to answer because there are enormous variations in the form and style of "picketing." The presence of an isolated picketer etches in the mind of the observer the futility of the picketer's cause, while a group of angry men may well convey a different, if unmistakable, message. In principle, it is possible to wait until the damage manifests itself, allowing only individual actions of assault by aggrieved customers. That course of action, however, is tantamount to leaving a wrong wholly unredressed. Individual citizens at the picket line can cut their losses simply by not crossing the line. In any event, they will not be induced to maintain a cause of action that promises only small rewards after arduous litigation. The real victim is the proprietor deprived of customers. The only effective means of social control, therefore, is to grant an action to the proprietor of the picketed establishment. This action itself requires no innovation in principle, even if it may call for some novelty in application. The old schoolmaster's case ${ }^{60}$ and Tarleton v. McGawley ${ }^{61}$ both granted

58. 3 W. BLACKSTONE, COMMENTARIES 120 (1790).

59. State Rubbish Collectors Ass'n v. Siliznoff, 38 Cal.2d 330, 336, 240 P.2d 282, 284-85 (1952). See W. PROSSER, HANDBOOK OF THE LAW OF TORTS 59 (4th ed. 1971).

60. This case is referred to in Keeble v. Hickeringill, 11 East 574, 576, 103 Eng. Rep. 1127, 1128 (K.B. 1809): "But suppose Mr. Hickeringill should lie in the way with his guns, and fright the boys from going to school, and their parents would not let them go thither, sure that schoolmaster might have an action for the loss of his scholars."

61. 170 Eng. Rep. 153 (K.B. 1793). 
actions for the (if it matters here, the deliberate) interference with prospective advantage by the threat or use of force.

To state the problem in this fashion is only to give some hint as to the problems that follow. Does picketing itself constitute a threat of force, or is it only an effort to convey information so that customers make an informed choice not to do business with the picketed establishment? In the celebrated case of Vegelahn v. Guntner, ${ }^{62}$ the court was forced to confront this very question in passing on the scope of an injunction awarded against two trade unions and their members. In making his preliminary determination, Justice Holmes noted that the defendants had engaged in two separate types of activities, the first involving the use of "persuasion and social pressure," and the second "threats of personal injury or unlawful harm," that were often conveyed in a disguised manner. ${ }^{63}$ The first of these he rightly treated as legal, and the second as illegal. The difficulty in the case was that the two patterns of behavior could be intertwined. Holmes tailored his original injunction to stop the second type of activity but to permit the first. In his dissent to the decision of the court, he justified his position by noting that if during the continuation of their picketing the defendants did use or threaten force, their conduct would fall under the injunction that he had granted so that the defendants would be "liable to summary punishment." The court in turn ordered a broader injunction that forbade the defendants from interfering with the plaintiff's business "by any scheme . . . organized for the purpose of ... preventing any person or persons who now are or may hereafter be . . . desirous of entering [the plaintiff's employment] from entering it." position is widely rejected today, ${ }^{68}$ and is open to condemnation as an excessive use of the injunctive power. Nonetheless, the court's judgment is not subject to any categorical denunciation, even if wrong. Thus, the broader injunction can be defended by pointing to the weaknesses of the finely tuned injunction that Holmes had adopted. Leaving the pickets in place by the plaintiff's business invites, or at least increases the likelihood of, the threat or use of force, which will go unredressed because the summary remedies available in principle are imperfect in practice. Case-bycase determinations are expensive to make, and are subject to very high error rates, especially where disguised threats are a substantial possibility.

62. 167 Mass. 92, 44 N.E. 1077 (1896).

63. 167 Mass. at 95-96. The passage is not reproduced in 44 N.E.

64. Id. at 104, 44 N.E. at 1080 (Holmes, J., dissenting).

65. Id.

66. See, e.g., Music Hall Theater v. Moving Picture Mach. Operators Local 165, 249 Ky. 639, 61 S.W.2d 283 (1933); People v. Nixson, 248 N.Y. 182, 161 N.E. 463 (1928). Vegelahn itself continued to enjoy some support. See Pierce v. Stablemen's Union, Local No. 8,760, 156 Cal. 70, 103 P. 324 (1909). 
In some cases at least, the best solution may give too much protection instead of too little.

The case for the majority position in Vegelahn becomes more plausible in light of the very powerful regulation of police behavior done today on constitutional grounds. At its root, Miranda v. Arizona ${ }^{67}$ rests upon the preference for broad over narrow injunctions, given that the simple appearance of a police officer can be so "inherently coercive" that constitutional rules of notice and right to counsel are necessary to help insure the "voluntariness" of a confession. The displaced rule-a case-by-case examination of the voluntariness of individual confessions-was rejected because it offered insufficient protection against official abuse. Picketing frequently constitutes an implicit threat of the use of force that may take the form of jostling or immediate contact. It may carry with it the implicit threat of the future infliction of harm: Who would not hesitate to cross a picket line if he saw a picketer filming persons crossing the line? To be sure, the picketers are not vested with the power of the state; but at the same time they are uncontrolled by any form of state power. The picketers can assert a weighty interest in freedom of speech, ${ }^{68}$ but this is matched by the interests in freedom of property, contract, and association on the other side.

The question is in the end a close call. To be sure, there are some easy rules that dispose of some challenges to picketing: One cannot, for example, prohibit picketing solely because of the content of its message-a proposition which no one denies. But when the easy cases have been set to one side, a broad class of situations remain in which the sound discretion of the trial judge will be necessary to determine whether an injunction should issue, and if so on what terms. The factually dense nature of the question, moreover, makes this type of determination inescapable whether we deal with a judge guided only by the general principles of equity, by an administrative officer trying to enforce the provisions of a coherent picketing control statute, or by the Supreme Court trying to determine the appropriate limits of the First Amendment guarantees of freedom of speech. There is simply no general form of words that will determine the appropriateness of or proper terms for an injunction. In some cases, it might suffice to reduce the number of pickets, or to limit the places where they may go. In others, the threat of force may be more severe, and the correct response far greater.

With this said, the limits of the libertarian theory should be evident. It

67. 384 U.S. 436 (1966).

68. See Thornhill v. Alabama, 310 U.S. 88 (1940). The subsequent course of doctrine has not been smooth. See, e.g., Hudgens v. NLRB, 424 U.S. 507 (1976); International Bhd. of Teamsters, Local 695 v. Vogt, Inc., 354 U.S. 284 (1957). 
only goes so far as to establish two propositions: (i) to condemn the use of force, and (ii) to mandate that injunctions be tailored to minimize the sum of the errors of over- and under-inclusion. Matters of future uncertainty cannot be handled neatly by any normative theory-including those which rely on general legislation. The wide range of considerations identified here must be taken into account in the treatment of picketing under the first amendment or under the New Deal legislation. It is not my task here to reconcile the decided cases, nor to defend the record of the preNew Deal courts in labor injunction cases. ${ }^{89}$ Given the degrees of freedom and uncertainty, no final indisputable reconciliation is ever possible. The law of injunctions here is if anything more difficult than the analogous problem in the law of nuisances. The best one can demand is to understand the nature of the end-the restriction of the use or threat of force-and choose the means most likely to achieve it. The very meaning of the phrase "sound discretion" is that there is an irreducible class of cases in which honest disagreements over proper disposition cannot be resolved in a conceptually rigorous manner. The great strength of the libertarian theory is that it identifies why picketing is a problem. But unlike the treatment of conspiracy or yellow dog contracts, picketing is a problem to which neither it nor any other theory provides a clean conceptual answer.

\section{Utilitarian Arguments}

The questions of malice, combination, yellow dog contracts, and picketing have thus far been considered solely from the vantage point of a strong theory of entitlements that (with the possible exception of picketing) in no way depends upon explicit utilitarian concerns. While much can be said to support the view that this general theory dispenses with the need to develop any alternative framework of analysis, the soundness of the conclusions urged above does not stand or fall on this single set of premises. The rival tradition of utilitarian thought is very powerful in the AngloAmerican philosophical and legal traditions. ${ }^{70}$ It can be fairly asked whether its explicit consideration calls for any modification of the conclusions already advanced.

In making this inquiry, one should note at the outset that in historical terms the utilitarian issues arise more in the interpretation of statutes than in the development of common law principles. Combination in restraint of trade is often seen today to invite a utilitarian analysis, but the common

69. For such a defense, see Petro, Injunctions and Labor Disputes: 1880-1932, Part I: What the Courts Actually Did-And Why, 14 WAKE FOREST L. REV. 341 (1978).

70. For a recent defense of the wealth maximization variant of utilitarianism, see Posner, Utilitarianism, Economics, and Legal Theory, 8 J. LEGAL STUD. 103 (1979). 
law cases that considered the legal status of unions never, either expressly or by implication, viewed the problem in a utilitarian light: ${ }^{71}$ The social welfare function was not the idiom of common law judges. The central inquiry in the cases was the proper delineation of individual freedom and the proper account of the "coercion" directed against the immediate parties to the dispute, usually rival unions or employers caught in the middle of picketing or jurisdictional disputes. The concept of the private damage action as a rough surrogate for social losses ${ }^{72}$ never surfaced in the cases.

The unwillingness of the common law to address the systemic economic issues meant that questions of social welfare were addressed, if at all, only in the great debate on whether labor unions should be subject to the sanctions of the Sherman Act, and later the Clayton Act, as combinations in restraint of trade. ${ }^{73}$ On its face, the language of the Sherman Act applies to labor unions as it does to any other aggregation of individuals. ${ }^{74}$ While the statutory construction and legislative history of the Sherman Act are complex, ${ }^{75}$ for our purposes the critical question is again normative: How should utilitarian considerations, in particular the antitrust laws, apply to labor unions?

One point of considerable importance is that the liberal and utilitarian traditions of analysis differ only in unimportant respects in their treatment of the enforcement of contractual arrangements between the parties to them. Thus the libertarian account will stress that the content of the obligation is no business of the courts, and will decline to look further at the matter unless fraud or misrepresentation or incompetence is present. The utilitarian will generally assume that contracts move resources to more valued uses, so that both parties to the agreement are better off under the agreement than without it. Duress, misrepresentation, and undue influence become relevant to identify those conditions in which the general proposition may not hold because one party has been prevented by the other from soundly assessing the desirability of his agreement.

The key difference between the liberal and the utilitarian approaches

71. Petro, supra note 31; Petro, supra note 69, at 436-46.

72. Cf. Easterbrook, Predatory Strategies and Counterstrategies, 48 U. CHI. L. REV. 263 (1981) (suits by victims of predatory pricing protect consumers at large).

73. The statute reads:

The labor of a human being is not a commodity or article of commerce. Nothing contained in the antitrust laws shall be construed to forbid the existence and operation of labor . . . organizations . . . or to forbid or restrain individual members of such organizations from lawfully carrying out the legitimate objects thereof; nor shall such organizations, or the members thereof, be held or construed to be illegal combinations or conspiracies in restraint of trade, under the antitrust laws.

15 U.S.C. $\S 17$ (1982).

74. See Loewe v. Lawlor, 208 U.S. 274 (1908).

75. See Winter, Collective Bargaining and Competition: The Application of Antitrust Standards to Union Activities, 73 YALE L.J. 14 (1963). 
lies in their evaluation of third-party effects. The liberal approach ignores shifts of wealth which are not preceded by a wrongful act such as the use of force or misrepresentation. ${ }^{78}$ The utilitarian theory, in contrast, attempts to take these pure economic externalities into account in order to counter perceived economic dislocations that cannot be rectified by agreement because of high transaction costs. In principle, the utilitarian limits contractual freedom whenever the loss of utility to third parties exceeds the gains to the parties to the original transaction. The analysis is complicated, since the transfer of any resource from $A$ to $B$ will as a matter of course alter the prospects, and hence the utilities, of $C$ through $Z$. In most situations, variations in the fortunes of third parties are regarded as random and offsetting, or as excessively costly to determine, and so they are rarely taken into account. The antitrust law-in particular the law of horizontal restraints of trade-is an effort to carve out a set of cases in which the systematic losses to society at large (measured by the failure to produce goods to the point where social marginal revenue equals social marginal cost) justify some restraint on freedom of contract.

It remains to see whether this general utilitarian approach requires us to revise the conclusions reached with respect to the four problems addressed above: malice, combination, yellow dog contracts, and picketing.

\section{A. Malice}

The structure of the utilitarian inquiry does not change the prior conclusion that malice is essentially an irrelevant factor in dealing with the legality of combinations of labor. ${ }^{77}$ Malice could be regarded as a type of satisfaction, equal to other satisfactions. Malice in its unalloyed form, however, is not an important element in situations dominated by economic self-interest and thus deserves little consideration, given the high costs of its isolation and punishment. Ignoring malice per se is especially untroublesome since many cases of malice will be caught by the prohibitions against duress and misrepresentation.

\section{B. Combination}

The question of combination raises very different concerns. The legality of organizing across industries may allow unions to obtain a degree of market power that, in the absence of their antitrust exemption, would trigger the application of the antitrust laws. The matter becomes particularly pressing once it is recognized that prohibitions against horizontal

76. This is the doctrine of damnum absque injuria-harm without legal injury. See generally Epstein, supra note 27, at $432-33$.

77. See supra pp. 367-69. 
arrangements between firms will be less effective if unions remain free to capture monopoly profits in the form of higher wages. One can argue that entry from nonunion firms will discipline the behavior of the unions, but under antitrust law the absence of legal barriers to entry need not be regarded as any more decisive in labor than in ordinary product markets. ${ }^{78}$ One could therefore extend the analysis quite naturally to argue that unions should be allowed to organize individual firms, but that no single union should be able to represent the workers of rival firms where a combination between those firms qua firms would represent impermissible market power. This compromise solution would permit unions to improve relationships between management and workers within the plant by handling personnel and public relation problems, ${ }^{79}$ but it would blunt their monopoly power. ${ }^{80}$ The effort to subject unions to antitrust laws therefore is supported by a coherent (if controversial) normative theory, even if the checkered history of the union exemption from antitrust laws itself defies rationalization.

\section{Yellow dog contracts}

The yellow dog contract is justifiable under the utilitarian as well as the libertarian analysis. Although it is commonly maintained that the yellow dog contract is unfair to the individual worker because of his weak economic position, ${ }^{\mathbf{8 1}}$ there is no reason why this should be so. Allowing employers to demand that their workers not join a union is very different from banning unions themselves. Any worker who accepts a yellow dog contract will demand some compensation for giving up the possibility of the gains of union membership. One has to assume an enormous degree of incompetence or ignorance by workers to ban the yellow dog contract on paternalistic grounds. ${ }^{\mathbf{8 2}}$

The analysis here is borne out by looking again at the terms of the yellow dog contract sanctioned by the Supreme Court in Hitchman. The wages, it will be recalled, were set at union scale. Indeed, the agreement

78. See supra note 73 .

79. For an account of unions that emphasizes this function, see Freeman \& Medoff, The Two Faces of Unionism, THE PUBLIC INTEREST, Fall 1979, at 69.

80. Efforts to gain monopoly power are clearly central to unionization. A desire only to smooth relationships between the management and the worker would not require the elimination of competition from nonunion plants, be it by the device of coercion or by secondary boycotts. Yet these techniques were and remain commonplace in labor relations. See C. GREGORY, supra note 35, at 217 (by the 1920's all nationally affiliated unions were committed to closed shop in every industry).

81. See Powell, supra note 3 , at 403-05.

82. Kennedy addresses the "distributive" and "paternalistic" justifications for the prohibition against yellow dog contracts in a discussion which seems to rest on the implicit assumption that the contract should be banned, apparently on the ground that such a ban enforces the solidarity among workers. See Kennedy, supra note 5, at 574-75. The question whether the interest of the workers in the plant should be equated with the social interest, however, is not addressed. 
provided for a retroactive wage increase if union wages increased after the start of the agreement, but for unchanged wages if union wages fell. ${ }^{83}$ "Union" wages implicitly understate the net wages to the nonunion workers, as union membership always imposes some obligations (dues, services) upon workers, wholly apart from the increased likelihood of substantial individual losses through strikes.

We must also take into account the duration of the contract, which was only at the will of both parties. The employer was not able to bind the workers for a fixed term, much less extract a promise from them not to join a union after they terminated their employment. This permitted workers who signed to keep the threat advantage of union membership without having to join one. They also gained an effective counterweight against any employer strategy of divide and conquer. By not signing a long-term employment contract, the workers preserved the option of joining a union at some subsequent time. Nor was the union precluded from organizing the workers while the yellow dog contracts were in effect. The ability retained by workers to quit and to join the union provided a valuable deterrent against the opportunistic behavior of the employer. ${ }^{84} \mathrm{Had}$ circumstances changed so as to make unionization more attractive, the workers would have been free to switch their allegiance. No worker who signs an employment contract today is disadvantaged in comparison to another employee who withholds his labor, for there is always an opportunity to reassess the basic situation. Indeed, a yellow dog contract does not even prevent the workers from quitting en masse and joining an existing union. The at-will feature of the yellow dog contract in Hitchman gave substantial protection to the workers, because the threat of unionization was always there.

The overall examination of the situation only confirms the general proposition that most contracts are in the mutual interest of the parties who sign them. The worker who signs a yellow dog contract may well be better off than one who does not. Certainly the terms of the arrangement in Hitchman cannot be explained by any theory under which an employer "dictates" terms to prospective workers. It is difficult to conclude therefore that these contracts, if reached, are necessarily the result of individual error and confusion, let alone desperation. The standard economic presumption of individual and rational self-interest better explains this case than theories of economic duress.

Our analysis of the yellow dog contract within the utilitarian framework is still not complete, however, because we have yet to take into ac-

83. 245 U.S. at 238.

84. On the problems of opportunism in contractual situations, see Muris, Opportunistic Behavior and the Law of Contracts, 65 MINN. L. REV. 521 (1981). 
count the third-party effects of agreements. The complaint is that union members must bear all the costs of the increased wage structure while the nonunion workers capture the same, if not greater, benefits. This claim seems inconsistent with a concern for the supposed incompetence of nonunion workers, since now nonunion workers are viewed less as the victims of the employers and more as the coexploiters of their union rivals. Nonetheless, as a factual matter there is much truth to this account, though it fails to take into account the ability of unions, especially if unconstrained by a duty of "fair" representation, to exclude outsiders from the benefits of membership. In the extreme case, exclusion takes the form of a closed union shop. Indeed, if unions improved productivity, employers would be willing to forgo yellow dog contracts and share the gains of unionization under a collective bargaining agreement that left both sides better off. Similarly, if yellow dog contracts caused employee demoralization and a resulting drop in productivity, the yellow dog contract would be unattractive. There is therefore no reason for legislative fiat if unionized firms can outperform their nonunionized rivals. If, however, union firms are less efficient than their nonunion rivals, why protect them by imposing legal restrictions upon their competition?

It seems clear that unions have some ways in which they can respond to the efforts of nonunion workers to free ride on union activities. On the other hand, any private responses undertaken by unions will be more costly to them than a legislative ban on the yellow dog contract. But the critical point is that the relevant class of third-party effects embraces all the society at large, not just unions. Suppose a group of producers asked the legislature to prevent rival firms who refused to join their cartel from selling in the market place. The short response is that combination amongst producers is the very thing that the antitrust laws are designed to prevent, so that the nonjoiners are beneficial in undermining monopoly control. Under our principle of neutrality, the nonunion worker is entitled to a similar place of honor, for the yellow dog contract helps constrain the monopolistic practices of unions and thereby reduces the need for direct government control over the unions by the antitrust laws.

Yet it may be said that there is really no social concern with the yellow dog contract at all, at least in those industries with competitive product markets. The union, the argument will run, simply will not be able to extract a monopoly profit because none is to be found. At best, this argument makes the libertarian case in favor of allowing the yellow dog contract decisive. But even if taken on its own terms, the argument is wrong because it ignores the struggle over economic rents ${ }^{85}$ that can coexist with

85. "The amount that a factor must earn in its present use to prevent it from transferring to 
competitive market structures. To revert to Hitchman, all coal deposits are not of equal value, as some are more difficult to extract than others, while some are farther removed from their natural markets. In a competitive system, the low-cost coal will be developed first. But in virtually all markets the aggregate demand will be satisfied only if some more expensive coal is sold as well. The very need to market the expensive coal now is incorporated into the increased capital value of the better situated deposits as economic rents. When a union organizes a mine, it obtains wages or other concessions that appropriate to its membership some portion of the economic rents attributable to the coal without forcing the price of the coal above the competitive level. The firm will of course respond to the threat by taking steps to resist unionization. The struggles over economic rents between mineowners and workers thus follow the familiar pattern, as real resources are expended only to obtain transfer payments, thereby causing substantial efficiency losses even in fully competitive product markets. The yellow dog contract is one low cost device that helps reduce the level of expropriation of rents by hindering union organization. The struggle over rents depends upon the formation of a bilateral monopoly, which is countered whenever employers can adopt contracting strategies that help maintain competitive employment markets. ${ }^{86}$ The great irony of Hitchman, then is that the location and immobility of the firm's key resource are the source of the economic rents that make the firm more vulnerable to individual exploitation than the individual workers. ${ }^{87}$ Workers, to be sure, do not have perfect mobility. Moving away from their homes can disrupt family and personal ties; changing occupations requires them to write off large investments in human capital. But the mass migration of workers through the early part of this century shows that labor has greater mobility than coal buried in the ground.

another use is called its transfer earnings; any excess that it earns over this amount is called its economic rent." R. LIPSEY \& P. STEINER, ECONOMICS 395 (2d ed. 1969).

86. See Klein, Crawford \& Alchian, Vertical Integration, Appropriable Rents, and the Competitive Contracting Process, 21 J.L. \& ECON. 297 (1978). The authors identify the quasi-rent value of an asset as "the excess of its value over its salvage value, that is, its value in its next best use to another renter." Id. at 298 . They then note that these quasi-rents can occur in a competitive market, be it in situations in which efforts are made by opportunistic individuals to expropriate gains after two parties have entered into a long-term contract, or in the case closer to that in labor markets, where there is a contest for rents during the precontractual period. Id. at 300 .

87. The fixed nature of the assets also explains why the firm cannot move to other locations where the labor markets are better, as in the case of the so-called "runaway" plants in textile and other industries. Note too that even where this mobility exists before a plant is opened, it is sharply reduced once a plant is placed in operation. 


\section{Picketing}

Picketing is the last practice to be examined under the utilitarian perspective. The analysis is simple enough. To the utilitarian, the general libertarian prohibition against the use of force is granted on the belief that gainful output will be reduced to the inconvenience of all whenever the producer is forced to share his gain with a stranger. ${ }^{88}$ Picketing that involves the use of force interferes with transactions that are otherwise beneficial, and it should thus be illegal. With the basic right established, the only question that remains is that of remedy. And here the utilitarian characterization of the problem is made explicit in the desire to reduce the sum of the errors of over- and under-enforcement. The two primary orientations thus yield the same outcome, with the same indeterminacies.

\section{Unfair Labor Practices}

The theoretical discussion of the common law rules provides a useful backdrop against which to analyze the major provisions of the Wagner Act. ${ }^{89}$ The basic protection to workers under the Act is contained in Section 7, which in its original form guaranteed that "[e]mployees shall have the right to self-organization, to form, join, or assist labor organizations, to bargain collectively through representatives of their own choosing, and to engage in concerted activities, for the purpose of collective bargaining or other mutual aid or protection." "90 Section 8 then sets out a group of five "unfair labor practices"-yet another instance of persuasive definition-that still lie at the heart of American labor legislation. ${ }^{91}$ Section 9(a) sets forth the basic structure of labor dynamics as bargaining in "good faith" between the employer and a union, the exclusive representative of the relevant employees:

Representatives designated or selected for the purposes of collective bargaining by the majority of the employees in a unit appropriate for such purposes, shall be the exclusive representatives of all the em-

88. See R. POSNER, ECONOMIC ANALYSIS OF LAW 121-22 (2d ed. 1977).

89. All citations here are to original act, e.g., $\S 8(1)$. The modern form of citation, e.g., $\S 8(a)(1)$, was introduced when the unfair labor practices by unions were added to the statute under $\S 8(b)$.

90. Wagner Act, ch. 372, $§ 7,49$ Stat. 449,452 (1935) (codified as amended at 29 U.S.C. § 157 (1982)). The act was subsequently amended to provide that employees "shall also have the right to refrain from any or all of such activities except to the extent that such right may be affected by an agreement requiring membership in a labor organization as a condition of employment as authorized in section 8(a)(3)." Labor Management Relations Act, ch. 120, § 101, 61 Stat. 136, 140 (1947).

91. Ch. $372, \S 8,49$ Stat. 449, 452-53 (1935) (codified as amended at 29 U.S.C. $§ 158$ (1982)). Amendments under Taft-Hartley established a similar set of unfair labor practices for unions. Labor Management Relations Act, 61 Stat. 136 (1947), amended, 73 Stat. 519 (1959), 87 Stat. 314 (1973), 88 Stat. 395 (1974) (codified as amended at 29 U.S.C. \& 158(a) (1982)). In my view the elaborate provisions of Taft-Hartley were in some measure a union victory, because they kept the original structure of the statute, making it more difficult to return to common law rules. 
ployees in such unit for the purposes of collective bargaining in respect to rates of pay, wages, hours of employment, or other conditions of employment: Provided, That any individual employee or a group of employees shall have the right at any time to present grievances to their employer .... ${ }^{92}$

It is not possible here to comment at any length on the enormous amount of litigation generated by the statute. ${ }^{93}$ What is important, however, is to give some sense of how the structure of the statute has altered the dynamics and the outcomes of labor negotiations. Several questions help mold the general inquiry: (i) How does the statute answer to both the liberty-based and utility-based visions of the law?; (ii) Can any special justification for the statute be found in the necessities of labor relationships?; and (iii) What is the relationship between the substantive rules and the emergence of the modern administrative state?

\section{A. Section 8(1): Coercion, Interference and Restraint}

Section 8(1) of the original Wagner Act made it an unfair labor practice "to interfere with, restrain, or coerce employees in the exercise of the rights guaranteed in Section 7." pear to work much of a departure from the previous common law rules. There is no question that the use of force by employers to prevent unionization by workers was both tortious and criminal at common law, and suits for interference with prospective advantage should be available to a union on exactly the same terms and conditions as they are available to the employer. If the statute had confined its operation to the traditional categories, its chief effect would have been to shift jurisdiction of labor disputes from the courts to the National Labor Relations Board. Nonetheless, the Wagner Act was drafted not to enshrine common law principles in the statute, but to throw a larger mantle of protection over unions and union activities, so that as a matter of statutory construction "coercion, restraint and interference" all assumed the broader meaning implicit in

92. 29 U.S.C. $\$ 159$ (a) (1982).

93. Much of it is collected in B. MELTZER, LABOR LAW: GASES, MATERIaLS AND PROBLEMS (2d ed. 1977); R. SMITH, L. MERRIFIELD, \& T. ST. ANTOINE, LABOR RELATIONS LAW (6th ed. 1979). For a hornbook treatment of the resulting law, see R. GORMAN, BASIC TEXT ON LABOR LAW, UNIONIZATION AND COLLECTIVE BARGAINING (1976).

94. Ch. $372, \S 8,49$ Stat. 449,452 (1935) (codified as amended at 29 U.S.C. $\S 158(a)(1)$ (1982)). This language tracks that of the Norris-LaGuardia Act, 29 U.S.C. § 102 (1982): "[I]t is necessary . . . that [the worker] shall be free from the interference, restraint, or coercion of employers of labor... "Norris-LaGuardia merely limits the scope of federal jurisdiction in injunction cases, however, while the Wagner Act creates substantive rights between the parties, see supra p. 1386. The constitutional doubts about the original Wagner Act were put to rest in Jones-Laughlin Steel Co. v. NLRB, 301 U.S. 1 (1937). The substantive challenges to the statute were never addressed, as Adair and Coppage were ignored, not refuted. 
the parallel provisions of the Norris-LaGuardia Act. ${ }^{95}$ The correlative duties imposed upon employers are therefore far more extensive than the common law, notwithstanding the section's ironic appeal to common law language. ${ }^{96}$ In the context of $8(1)$ this broader construction has affected two types of behavior: attempts by the employer to keep his premises free both from organizational activities of the union and from employer speech.

At common law, the employer, like everyone else, was entitled to the exclusive possession and use of his own property. Persons who wanted to enter ${ }^{97}$ or remain upon ${ }^{88}$ property could do so only with the owner's consent and under the terms and conditions that he saw fit.

These rules could have been carried over to labor disputes. Nonetheless, in a manner consistent with the general philosophy of the Act, the cases have consistently held that any restriction or prohibition of union activity on company property constitutes an "interference" with Section 7 rights, which must therefore be justified by showing that some competing interest of the employer outweighs the rights of employees under Section 7 of the Act. Within this balancing framework the decisions exhibit a commendable logic. Thus the cases have generally curtailed union activity on the workshop floor during working hours, especially when it may be carried on elsewhere with little disruption, as in the employees' lunchrooms during mealtimes and work breaks. ${ }^{90}$ Similarly, the cases have granted the employer a greater right to exclude outside organizers from his premises than to exclude workers already on the premises. ${ }^{100}$ And, more questionably perhaps, the cases have given far greater rights to unions seeking economic advantage compared to those who want political influence. ${ }^{101}$

My concern here, however, is not with the reasonableness of the decisions under the statute, but with the soundness of the statute itself. The

95. See also supra note 94 (parallel provisions of Norris-La Guardia).

96. See Hitchman, 245 U.S. at 263 (Brandeis, J., dissenting).

97. The only exception to the rule was for the rare cases of personal necessity, which applied only to persons in imminent peril of life or limb, and then only on very restrictive terms: The passing of the necessity terminated the privilege, and compensation was required for any damage caused by the entrance. See, e.g., Vincent v. Lake Erie Transp. Co., 109 Minn. 456, 124 N.W. 221 (1910); RESTATEMENT (SECOND) OF TORTS § 263 (1965). See generally Bohlen, Incomplete Privilege to Inflict Intentional Invasions of Interests of Property and Personality, 39 HARV. L. REV. 307 (1926).

98. See W. PROSSER, supra note 59, at 73-74: "The trespass may also be committed by remaining on the land after a right of entry has terminated. Thus it is a trespass to refuse to leave after a license to remain has been revoked, or to fail to remove property at the end of an agreed period."

99. Beth Israel Hosp. v. NLRB, 437 U.S. 483 (1978); Republic Aviation Corp. v. NLRB, 324 U.S. 793 (1945). The reach of Republic Aviation is shown by the Court's quick rejection of the argument that the anti-solicitation rule could not be an unfair labor practice because it was introduced long before the passage of the statute, 320 U.S. at 804-05, and applied to all solicitations, whether or not labor related, $i d$. at 805 . Both those points are relevant to the question of employer motive, which is in the balancing process displaced by considerations of the effect of the restriction upon activity.

100. NLRB v. Babcock \& Wilcox Co., 351 U.S. 105 (1956).

101. See Hyde, Economic Labor Law v. Political Labor Relations: Dilemmas for Liberal Legalism, 60 TEX. L. REV. 1 (1981). 
central mistake of the statute as construed is that it introduces any balancing test at all. Any balancing under the Act, however reasonable, quite clearly cuts back upon the absolute power to exclude that is the hallmark of any system of private property. ${ }^{\mathbf{1 0 2}} \mathrm{It}$ is wholly incorrect to treat as coercive any action by an employer that works to the economic detriment of union members. The real question is whether a firm should be required to provide an in-kind subsidy to a union regarded as antithetical to its prosperity, and perhaps to its survival. Employers need not make cash contributions to unions; why must they make contributions in kind? If it is argued that access to the property may be critical to an organization drive, then the answer is that denial of access is equally critical to the employer. Here as elsewhere the relative needs of the parties do not in any sense determine the proper set of initial entitlements, but only the subsequent business question whether they will strike some bargain that works to their mutual advantage. There are many ways in which a union could use its own resources to advance its cause, e.g., meetings, leaflets, or campaigns. There is no principled reason why a union should be able to impress a lien upon the property of the employer for its own advantage.

A similar analysis applies to the question of employer speech. In its early decisions, the Labor Board found that any speech by an employer designed to induce its employees to stay out of the union was coercive and improper. ${ }^{103}$ In particular, special and vigorous condemnation was found for speeches in which the employer stated that he would bargain hard against the union, close his shop and move elsewhere, or eliminate some of the benefits to which his employees had grown accustomed. As a matter of principle, however, it is hard to imagine how suppression of truthful information could serve the interest of employees faced with deciding where to cast their lot. To be sure, one can understand why a prohibition against employer fraud might be required. But antifraud devices are notoriously difficult to apply to the bluffing that always goes on in hard contractual negotiations, where complex matters of fact are involved. Indeed, if any deviation from the common law rules were to be required, the rules against fraud might be relaxed; the likelihood of a prompt union response is a credible deterrent against fraud, which although imperfect suffers from none of the complexities of the common law action.

Nonetheless, the labor rules go quite beyond that limited objective of the prevention of fraud, attempting to assure something akin to employer

102. The constitutional status of the statute is not the concern here, since the tangled web of cases on the protection afforded possession under the eminent domain clause defies coherent exposition. See, e.g., Loretto v. Teleprompter Manhattan CATV Corp., 458 U.S. 419 (1982); Pruneyard Shopping Center v. Robins, 447 U.S. 74 (1980); Kaiser Aetna v. United States, 444 U.S. 164 (1979).

103. See R. GORMAN, supra note 93 , at 148-49. 
neutrality on the question of unionization. ${ }^{104}$ The point, however, is hardly one on which employers should be expected to be neutral, given their enormous self-interest in the question of firm organization. Putting to one side the serious constitutional questions, there is no independent account of coercion (or fraud) that can justify in principle the statutory restrictions of the rights of employers to bargain hard and to speak their piece. Speech itself is a proper subject for regulation when it threatens coercive action, but, as before, coercive action must be confined to reach only the threat or use of force or the breach of promise. Speech cannot be redefined as coercive simply by expanding through legislation the list of activities that are prohibited by law. As with the rules of company property, however, the statute appeals to traditional liberal fears of coercion and restraint, but uses them to justify the government control that any sound legal order should condemn.

Section 8(c) of the Taft-Hartley Act ${ }^{105}$ reveals the extent to which the rules governing employer speech depart from those required by the principles of defamation and misrepresentation:

The expressing of any views, argument, or opinion, or the dissemination thereof, whether in written, printed, graphic, or visual form, shall not constitute or be evidence of an unfair labor practice under any of the provisions of this Act, if such expression contains no threat of reprisal or force or promise of benefit. ${ }^{108}$

The section makes perfectly good sense-save for the final "if such expression" clause, which is in truth all that matters. The statute is clearly overbroad in its operation, for it does not ask whether there are less restrictive means to achieve the legitimate end of public control against truly coercive behavior. The "reprisal" language is also prey to all the criticisms of the statutory use of "interference, coercion and restraint" under Section 8(1). The far broader language of "promise of benefit" further compounds the original difficulty: The promise of a benefit is simply not the equal of the threat of force, even if it contains the implicit (but lawful) threat to withhold the benefit if the union is recognized. The current case

104. See NLRB v. Federbush Co., 121 F.2d 954, 957 (2d Cir. 1941) (Learned Hand. J.): Arguments by an employer directed to his employees have such an ambivalent character; they are legitimate enough as such, and pro tanto the privilege of "free speech" protects them; but, so far as they also disclose his wishes, as they generally do, they have a force independent of persuasion. The Board is vested with power to measure these two factors against each other, a power whose exercise does not trench upon the First Amendment . . . . What to an outsider will be no more than the vigorous presentation of a conviction, to an employee may be the manifestation of a determination which it is not safe to thwart. The Board must decide how far the second aspect obliterates the first.

105. 29 U.S.C. $\S 158$ (1982).

106. Id. § 158(c). 
law on the question recognizes that an employer is entitled to say something in opposition to a union. That case law insists, however, that under the statute "an employer is free only to tell 'what he reasonably believes will be the likely economic consequences of unionization that are outside his control" and is not free to make "threats of economic reprisal to be taken solely on his own volition." ${ }^{107}$ One can quarrel with this formulation on the ground that it reduces the law of employer speech to a discourse on grammar, style, and nuance that emphasizes the hidden virtues of the passive voice. But if in fact the basic structure of rights under the NLRA is correct, then this distinction, however murky, is about as serviceable as any that might be adopted. The structure of the NLRA is defective, however, and accordingly the decisive objection to the test is that it fails to explain why economic reprisals short of the use of force can be condemned. If the employer is entitled to close down his plant, or to hire non-union labor, then how can he be prevented from threatening what he has a right to do? ${ }^{\text {108 }}$

\section{B. Section 8(2): Company unions}

Section 8(2) makes it illegal "to dominate or interfere with the formation or administration of any labor organization or contribute financial or other support to it."109 There is little need to dwell at length on its oddities and difficulties. The prohibition against company support and contribution to a union was justified on the ground that company unions make a "sham" of the process of collective bargaining"10 by placing the employer on both sides of the bargaining table. This characterization misstates the nature of the bargaining process: The employers must still bargain with workers to hire and retain them. If the company union imposes costs upon the workers, then the employer will have to make appropriate adjustments elsewhere to maintain the quality of his workforce. Given a company union, the adversity of interest between the parties simply manifests itself before the worker joins the union instead of afterwards, while the protection against opportunism is provided by the at-will feature of the employment agreement. In any case, it is difficult to see why Congress should prohibit by law certain forms of labor organization. In a nation that treasures diversity, why is it so unreasonable for certain workers to decide that they wish to join a company-sponsored union? As with

107. NRLB v. Gissel Packing Co., 395 U.S. 575, 619 (1969) (citing NLRB v. River Togs, Inc., 382 F.2d 198, 202 (2d Cir. 1967)).

108. For an expression of the view that generally one ought to have a right to threaten to do that which one has a right to do, see Epstein, Blackmail, Inc, 50 U. CHI. L. REV. 553 (1983).

109. 29 U.S.C. $\$ 158(\mathrm{a})(2)(1982)$.

110. See, e.g., 78 CONG. REC. 3443 (1934) (statement of Senator Wagner). 
yellow dog contracts, workers will not surrender their rights to remain out of the company's orbit for nothing, and they may well gain substantial benefits from the internal procedures that prevent individual grievances from becoming the source of major employee discontent.

Making employer sponsorship of worker participation an unfair labor practice protects not the workers in the plant, but rather the unions that might want to organize the workers. Yet even here the irony is clear, for the prohibition against company "contributions" complicates negotiations for unions that have gained representation rights under the statute. Every union must obtain funds from its members, funds which typically come out of wages. The union and the employer may well wish to negotiate a direct payment from the firm to the union if that is agreeable to both. ${ }^{111}$ As this is prohibited by the statute, ${ }^{112}$ however, the union must collect the dues from its members. It is generally cheapest for the union to do so through a dues check-off system with the employer. This dues check-off is allowed under the statute, but cannot be imposed over the objection of the employer. ${ }^{113}$ From the union point of view, however, a dues check-off is inferior to direct payment because it does not permit the charges to be levied against non-member workers within the bargaining unit. Here as before, the entire structure of the Act depends upon its perverse limitation of freedom of contract, which necessarily requires the substitution of a regime of complicated arrangements for simpler ones.

\section{G. Section 8(3): Dismissal Motivated by Union Affiliation}

Section $8(3)$ forbids the employer "by discrimination in regard to hire or tenure of employment or any term or condition of employment to encourage or discourage membership in any labor organization."114 This language makes it an unfair labor practice for an employer to hire only workers who agree not to join any union. The limitations under Section $8(3)$ are far greater than the simple legislative prohibition of the yellow dog contract. No employer needs a yellow dog contract to fire workers who decide to organize or join a union. A contract at will is quite sufficient for that purpose; at common law, the explicit contractual provision

111. The employer might not want to provide a service which costs the union little and contributes materially to its strength. The real cost to the employer is the enhanced power conferred upon the union, not the tiny administrative expenses; yet to speak of them without sufficient justification is to invite charges of unfair labor practices under $\$ 8(5)$ of the Act. Again, therefore, candor yields to a discussion of irrelevant points of detail. But then the sensible response is to allow the employer to refuse to provide either dues check-offs or direct payments unless he agrees to do so by contract.

112. 29 U.S.C. $\S 158(\mathrm{a})(2)$ (1982).

113. H. K. Porter Co. v. NLRB, 397 U.S. 99 (1970).

114. 29 U.S.C. $\S 158($ a)(3) (1982). 
was critical against third-party inducement, as in Hitchman. ${ }^{115}$ The arguments against the anti-yellow dog provisions of Norris-LaGuardia apply a fortiori to the far more intrusive restrictions of the Wagner Act. The employer must continue to employ individuals whose loyalties are known to clash with their duties toward the employer, even though the success of the operation of the firm may well depend upon complete loyalty. Nor can it be said that the issue is a minor affair, though Holmes characterized it as such in his dissent in Adair. Membership in a union may be only one feature of a contract that contains a vast number of terms, but it is the one term that skews all the rest. Unions fought hard for Section 8(3) because they perceived it as critical to their success; one can easily imagine their response to its possible repeal.

It may be urged nonetheless that Section 8(3) is needed to protect workers not against the employer as such, but against foremen who engage in various capricious actions against the employee, including demands for favors and kickbacks. ${ }^{116}$ The remedy for this ill, if it exists, is not the passage of Section 8(3) or any other labor statute. The problem is one of conflict of interest between principal and agent, often discussed under the heading of "agency costs."117 Any abuse by the foreman diverts income from the employer and reduces the profitability of his operations, for while kickbacks may come out of the pockets of employees, the economic effect is indistinguishable from a direct payment of part of the workers' wages by the firm to the foreman. Since the workers care about their net salary, they will demand higher wages to compensate for the loss. The firm therefore has a strong financial incentive to monitor the behavior of its supervisory personnel wholly apart from Section 8(3).

The institutional structures established by Section 8(3) impose additional costs as well. The preferences of firms for non-union labor will not disappear with the passage of a statute. Indeed, since the statute increases the costs of unionization to the employer, unions will be less welcome after the Act than before it. As such, we should expect that employers will take elaborate measures to avoid unionization when they are barred from resorting to the simple contractual expedient. Efforts (often surreptitious) may be made to screen prospective employees for their past union affilia-

115. Adair v. United States, 208 U.S. 161, 191 (1908) (Holmes, J., dissenting). The definition of "employer" contained in $\S 2(3)$ was modified to exclude "any individual employer as a supervisor." On the origins of this important structural provision, see $R$. GORMAN, supra note 93, at 34-35. This definitional exception places a very powerful roadblock against union power, and the balance under the statute would be very different without it. It is one of the features that helps keep the balance of power under the Act.

116. See Winter, supra note 75 , at $24-25$.

117. See generally Jensen \& Meckling, Theory of the Firm: Managerial Behavior, Agency Costs and Ownership Structure, 3 J. FIN. ECON. 305 (1976) (discussing conflicts of interests that pervade principal-agent relationships). 
tions or present union sympathies. The organization, practices, and layout of a plant may be restructured to make it difficult for a union to know what workers do or where they live. These counterstrategies may constitute unfair labor practices under the statute, but the risk of their being identified as such will be treated in part as one of the costs that the firm is prepared to bear in order to escape the union. Whether the stratagems succeed or fail, it is quite clear that the statute channels resources into anti-unionization efforts-including the ubiquitous employer consultants. These same resources could be spent on the production of real goods and services if employers were allowed to use contractual measures to meet their objectives, which are, it must be stressed, legitimate under any normative overview of the question.

\section{Bargaining in "Good Faith"}

There is still a need to consider the last of the key unfair labor practices, that of an employer's refusal to bargain-judicially construed to mean bargaining in "good faith"-with the union, a mandate closely and necessarily linked to the exclusive representation provisions of Section 9. The question itself requires an examination of the relationships between the employer and the union and between the union and its members.

\section{Conflicts Between Employer and Union}

In order to understand the dramatic impact that the Wagner Act has had on employer-union relations, it is necessary to recall that the common law imposed no regulatory obstacles upon any collective bargaining agreement. Such agreements did occur before the passage of the Wagner Act, and their provisions were rightly held to bind employers as well as employees. ${ }^{118}$ Yet here, as with individual contracts of employment, a court's sole function was to enforce agreements already made. It did not have to coerce the agreement itself; nor was it required to police the environment in which an agreement was being negotiated, beyond applying the usual rules of fraud and duress.

118. See Schlesinger v. Quinto, 201 A.D. 487, 498 (1922). There can of course be difficulties in enforcing these collective bargaining agreements. The union may be treated as an unincorporated association that has no legal status, see, e.g., Karges Furniture Co. v. Amalgamated Woodworkers' Local Union No. 131, 165 Ind. 421, 75 N.E. 877 (1905); Pickett v. Walsh, 192 Mass. 572, 589, 78 N.E. 753, 760 (1906), which therefore could not sue or be sued in its own name. Other problems may stem from the fact that a collective bargaining agreement is not the same as an individual contract for employment, but only creates "a trade agreement" which forms the basis for individual employment contracts. See J.I. Case Co. v. NLRB, 321 U.S. 332, 335 (1944). These difficulties could have been resolved in ways that eliminate the obstacles against contractual freedom, however, rather than ways that override it. The judgment of Justice Jackson in J.I. Case contains the clearest possible acceptance (if not to say endorsement) of the principle that individual vested rights under a contract must yield to the collective good in order to implement the statutory scheme of the labor acts. 
The passage of the Act, however, radically changed the nature of labor negotiations. In the previous situation, any refusal to make an agreement meant only that there was no agreement. Breaches of the duty to bargain in "good faith" were generally confined largely to matters of fraud in the inducement of contract. Otherwise the duty of good faith was confined to the infrequent cases in which there was some (non-negligent) precontractual "justifiable" reliance by the other party. ${ }^{118}$ Limited in this way, the principle of "good faith" clearly has no bite in the area of labor relations, as employers easily can avoid the twin pitfalls of pre-contractual reliance and misrepresentation. One alternative is simply to refuse to negotiate with a union at all. Still another is explicitly to inform the union as a precondition to negotiation that it will have to bear its own costs in the event that some agreement is not reached.

The statute changes the legal environment, however, by imposing an affirmative duty to bargain. It demands therefore a theory of good faith consistent with the expanded duties that it imposes. Such a theory is not easy to develop. To be sure, one can begin to solve the problem by making the obvious point that the obligations require parties to comply with elaborate procedural requirements about the times and conditions of negotiations. Nonetheless one may also wish to honor the statute's ostensible support of freedom of contract by insisting (as did the Taft-Hartley provisions) that the obligation to bargain collectively in good faith "does not compel either party to agree to a proposal or require the making of a concession." ${ }^{\prime 20}$ Yet there is an enormous gulf between a statute that rules out the obvious extremes and a workable rule for the many cases in which negotiations do not end in agreement. The case law on the question is an exercise in futility. ${ }^{121}$

The difficulties with the duty to bargain in good faith under the labor statute are perhaps clarified by a comparison with the issue of settlement in both the civil and the criminal law. In the civil case, litigation is settled

119. "[The law] has to provide for the restoration of the status quo by giving the injured party his negative interest or reliance damages. The careless promissor has only himself to blame when he has created for the other party the false appearance of a binding obligation. This is the meaning of culpa in contrahendo." Kessler \& Fine, Culpa in Contrahendo, Bargaining in Good Faith, and Freedom of Contract: A Comparative Study, 77 HARV. L. REV. 401, 402 (1964).

Kessler and Fine then give other instances in which the doctrine of culpa in contrahendo has been applied: incomplete agreements, informal agreements, silence, and want of an intention to contract. Id. at 412-20. None of these impose restrictions of any institutional importance for labor-management relations.

120. See National Labor Relations Act, $\S 8(d), 29$ U.S.C. $\S 158(d)$ (1982), which was added to the Act in 1947.

121. For examples of the types of problems courts encounter in defining "good faith," see, e.g., NLRB v. General Elec. Co., 418 F.2d 736 (2d Cir. 1969), cert. denied 397 U.S. 965 (1970); NLRB v. Katz, 369 U.S. 736 (1962); NLRB v. Insurance Agents' Int'I Union, 361 U.S. 477 (1960); NLRB v. Truitt Mfg. Co., 351 U.S. 149 (1956); NLRB v. American Nat'l Ins. Co., 343 U.S. 395 (1952). 
with each party acting under the threat of coercion from the other side. ${ }^{122}$ In contrast to most markets, neither party can go elsewhere if he does not like the offer received from the opposing side. The same is true about plea bargaining in the criminal context; the accused does not go free if he cannot strike a deal with the prosecutor. ${ }^{123}$ With the duty to bargain in good faith, the labor situation is transformed from the market case to the litigation case. Protracted negotiations can take place to determine the ultimate outcome of what is, when all is said and done, a legally created bilateral monopoly. No nascent standard of good faith effectively constrains these negotiations, any more than it does for civil settlement or plea bargaining. The most that good faith can demand is that the parties not press claims or defenses known by them to be groundless. But this constraint is of virtually no relevance in the labor context, where the matters in dispute are economic demands, rather than the soundness of legal theories.

In civil litigation a bilateral monopoly results whenever voluntary transactions fail. Because there is no competition between borrowers in the collection market, resort to state-controlled coercion is indispensable. Likewise, the monopoly control of the state over criminal enforcement makes it quite impossible to avoid the bilateral monopoly problem under any system of criminal prosecution, with either public or private enforcement. Yet employment negotiations provide no comparable necessity for the creation of a complex institutional structure at contract formation. On matters of money and conditions of employment, the very notion of good faith has no internal intellectual coherence because there is no theory of the just contractual outcome to which it can be tied. All that can be done is to penalize individuals for candor (as with Boulwarism) ${ }^{\mathbf{1 2 4}}$ or inexperience, and to inject an element of public oversight that can only complicate any real negotiation.

Even without the passage of the Wagner Act, one can expect some very difficult negotiations between employers and workers over the division of the pie. Yet the statute, by making the union the exclusive bargaining representative, increases both the costs of negotiations and the likelihood that no effective agreement will be reached. The parties will play "noncooperative" games with each other; their bluff and bluster will increase the chances of a strike, even if both sides would have been better off with

122. See Cook v. Wright, 1 B. \& S. 559, 568-69, 121 Eng. Rep. 822, 826 (Q.B. 1861).

123. For a discussion of the difficult bilateral monopoly problems in plea bargaining, see Easterbrook, Criminal Justice as a Market System, 12 J. LEGAL STUD. 289, 291 (1983).

124. The practice involved the decision of the employer to make one "fair, firm offer" to the union which it treated as inflexible. The offer was also accompanied by a barrage of publicity designed to persuade the workers that the union demands were astronomical. See NLRB v. General Elec. Co., 418 F.2d 736, 756-62 (2d Cir. 1969) (practice violates § 8(a)(5)). 
some agreement sparing them the extensive costs of strikes. ${ }^{125}$ Matters only become more complicated when the response to unionization includes the possibility of industry-wide bargaining, or the concentration of economic pressure on some firms in the industry, perhaps after a quick settlement with others. ${ }^{128}$ The increased frequency of impasse in turn gives greater scope to the Act's unfair labor provisions, which are sufficiently elastic to allow a colorable claim to be filed with the Board whether or not some agreement is reached. The creation of exclusive rights of representation coupled with duties to bargain shows the want of wisdom in replacing simple institutional arrangements with very complex ones.

The bargaining structure under the Act also increases third-party costs, as other individuals and firms are forced to reorganize their own affairs to respond to increased costs and lower reliability of the current labor structure. ${ }^{127}$ Tracing the consequences through a chain of customers and suppliers raises administrative complexities sufficient to daunt the spirit of any common law court, which largely explains the common law's unwillingness to give much protection for interference with prospective advantage. ${ }^{128}$ The preferred solution is to eliminate the structures that cause these dislocations. As political pressures have prevented the repeal of the Wagner Act, the response to the unfortunate status quo ante has been further government intervention to restore some balance to the system. The insistence upon "good faith" negotiations is one such effort. "Cooling off" periods and special congressional mandates to suspend or limit particular strikes are another; ${ }^{\mathbf{1 2 \theta}}$ federal limitations on secondary boycotts are yet a third; ${ }^{130}$ and federal mediation services a fourth. ${ }^{131}$ Yet since no one

125. The 1982 strike by the National Football League Players is a good example of such a situation. For an account of the strike, see The NFL Players Run Out of Time, BUS. WEEK, Nov. 29, 1982 , at $35-36$.

126. For the modern case law, see American Shipbuilding Co. v. NLRB, 380 U.S. 300 (1965); NLRB v. Brown, 380 U.S. 278 (1965).

127. These costs should obviously be taken into account under a utilitarian analysis. They must be considered under a libertarian perspective as well, for these dislocations are the product of improper statutory restrictions upon the freedom of the employer's right to negotiate at will with whomever he pleases.

128. See, e.g., Robins Dry Dock \& Repair Co. v. Flint, 275 U.S. 303, 308 (1927); Byrd v. English, 117 Ga. 191, 194, 43 S.E. 419, $420-21$ (1903). See generally Rizzo, The Theory of Economic Loss in the Law of Torts, 11 J. LEGAL STUD. 281, 291-96 (1982) (limited recovery for loss of prospective advantage designed to "channel" suits through limited number of plaintiffs).

129. See Labor Management Relations Act, $\$ \S 201,206-210,29$ U.S.C. $\$ \S 171,176-180$ (1982). Section 201 states the problems under the old order. Sections 206 to 210 address the mandatory powers of the President in emergency situations, and include the powers to enjoin both strikes and lockouts.

130. See National Labor Relations Act, $\S \S 8(b)(4)$ to $8(b)(7), 29$ U.S.C. $\S \S 158(b)(4)-158(b)(7)$ (1982).

131. Section 202 of the Labor Management Relations Act, 29 U.S.C. $\S 172$ (1982), creates the Federal Mediation and Conciliation Service, whose powers are defined in $\S 203$ of the Act, 29 U.S.C. $\S 173$ (1982). 
can fine tune so complicated a mechanism, every effort at adjustment itself imposes additional tensions upon the system. The elimination of the basic structure is necessary, not the further embellishment of the regulatory pyramid.

\section{Conflicts Between Employees}

Sections 8(5) and 9(a) are also troublesome from the perspective of the employee as well as the employer. When the statute says that employers may not enter into direct negotiations with individual employees over the terms and conditions of employment, it imposes restrictions upon employees and employers alike. The justification offered for this exclusive right of negotiation is that without it the employer will skim off the best workers and discriminate against union supporters, thereby depriving the union of its strength. The discussion of this issue in connection with the yellow dog contract is sufficient to show that, while the factual assertion may be true, the asserted equation of the union with the social interest is not.

The problem here goes to the root of representative government. Under the older common law system, in the original position, each individual worker had a clear and well-defined set of rights good against the world. He was therefore entitled to bargain those rights away to either the union or the employer for whatever consideration he saw fit. The determination of rights under the system of collective bargaining creates far greater stress. Now no party derives its rights by agreement from a clear original position. Instead, a majority of the workers within an appropriate unit may choose the union as the bargaining representative of that unit. Thereafter the union represents both its supporters and its opponents within the unit, whether or not they are union members. The original entitlements are very much in doubt. The "union" interest itself is no unitary whole, but instead a complex amalgam of the individual interests of the many actors who play on the expanded stage. It is no accident that extensive administrative procedures are needed to determine the contours of an "appropriate bargaining unit" and to enforce fiduciary duties for the protection of minority interests.

In defining bargaining units, no vote can determine who is eligible to vote, nor can any simple principle, like territoriality or citizenship, serve that function. Voluntary arrangements are excluded by the very structure of the Act, for even if the union and the employer agree on the definition of the unit, and their determination is accepted by the Board, that determination is made in a legal environment where the employer is subject to statutory obligations that effectively limit his domain of choice. With negotiation from a set of original entitlements precluded, only a complex but 
formless weighing of "relevant factors" remains. Does one establish units by plant, by firm, or by craft? Is an agreement between the union and the company sufficient on the question? Or must the interests of anti-union workers or rival unions be taken into account? What about potential employees? The various shifts in preference between large trade unions and small craft unions reflect not only the powerful political divisions on the Board ${ }^{132}$ but the utter impossibility of finding any neutral principle of coerced organization to replace the consensual formation of unions. ${ }^{133}$ In addition, a host of tactical questions arise within a regulatory framework where an employer cannot simply walk away from a demand for unionization. Should the employer agree to a union for some fraction of its work force, hoping to stave off the unionization of its entire operation? Does a union have sufficient strength in certain core areas to risk seeking a plantwide unit? What position, if any, should an employer take when it fears one of two rival unions more than another? Any system that allows unionization will have to bear some costs of organization. But at least the principle of selection in a voluntary system is clear enough. Those who agree to join are members, and none else. The statutory scheme imposes a much more complicated regime. Its costs are evident enough. Where are the benefits?

The problem of protecting the interests of a minority within a union is equally complex. One might allow the union to parcel out the benefits of unionization within the unit in any way it chooses, subject only to the constraint of continuing to command the support of a majority of the unit. This constraint is not as trivial as it sounds: If the union pushes too hard on some minority group within it, it risks the loss of that minority's support or even possible decertification if the minority was previously the block whose support allowed the union to command a majority. The possible gains from unionization can be distributed in countless ways without running afoul of these constraints. So too where the industry is in decline, although the distribution of losses in wages and benefits raises even more acute problems.

What additional legal constraints might limit the powers of unions to distribute the pie in whatever manner they see fit? There is the obvious fear that a union (or its dominant coalition) will discriminate on the basis of race, sex, religion, or national origin to benefit some members at the expense of others. Indeed, the duty of "fair representation," read into the

132. On the impact of politics on the composition of the Board, see F. MCCuLlocH \& T. BORNSTEIN, THE NATIONAL LABOR RELATIONS BOARD 60-62, 107-09, 112-14 (1974).

133. For examples of the issues involved in certifying a bargaining unit under the NLRA, see, e.g., Local 1325, Retail Clerks Int'l Ass'n v. NLRB, 414 F.2d 1194 (D.C. Cir. 1969); Mallinckrodt Chem. Works, 162 N.L.R.B. 387 (1966). 
Wagner Act as a counterweight to union power, addressed these forms of discrimination even before the passage of the modern anti-discrimination laws. ${ }^{134}$ This restraint, however, covers only a tiny fraction of the possible situations. Within a single unit, for example, the majority of unskilled workers may capture much of the surplus created by unionization for themselves by reducing the wage differentials between skilled and unskilled workers. The same problem may occur with the merger of separate seniority lists arising from the merger of separate plants or firms. ${ }^{135}$ In the extreme case, individual workers may be required to give up benefits they secured under contract before the recognition of the union. ${ }^{136}$ Yet even if some prohibition were placed upon tampering with vested rights, there is little to prevent the dominant coalition within the union from undercutting their value by reducing the future share of the common pool for the protected workers. ${ }^{137}$

As the problem itself arises from the unconstrained operation of majority will, the only bulwark against these abuses must depend upon some rule of "fairness" for the distribution of the surplus among all possible claimants. This theory of fairness cannot emerge from a consistent view of individual rights to liberty and property, for that theory flatly condemns the system of coerced collective bargaining on which labor law rests. The required vision of fairness therefore must come from a theory of forced exchanges. That theory, which lies at the root of a theory of eminent domain, in turn requires that those whose rights are taken receive in exchange rights that leave them at least as well off as before. ${ }^{138}$ Unfortunately, difficulties block the application of this theory in the labor context.

First, the baseline against which the subsequent benefits should be measured must be determined. In principle this baseline could be the position that an individual worker would have achieved under the common law system; however, this is the one baseline which the labor law, with its insistence upon "full" freedom of contract, has rejected. The common law baseline could bar certain distributions reached under collective agreements, including any in which some workers receive less under collective

134. The first important case was Steele v. Louisville \& Nashville R.R. 323 U.S. 192 (1944), which held that the Railway Labor Act imposed on a labor organization representing a craft or class of employees, the duty not to discriminate on the basis of race in the course of representation. Although Steele was decided under the Railway Labor Act, the same principles have been carried over to the National Labor Relations Act. Miranda Fuel Co., 140 N.L.R.B. 181 (1962) (employee right to fair and impartial treatment under the NLRA).

135. See generally Freed, Polsby \& Spitzer, Unions, Fairness, and the Conundrums of Collective Choice, 56 S. CAL. L. REV. 462 (1982).

136. See generally id. at 484-87 (noting possibility of prospective wage adjustments).

137. See J.I. Gase Co. v. NLRB, 321 U.S. 332, 338-39 (1944).

138. See Michelman, Property, Utility, and Fairness: Comments on the Ethical Foundations of "Just Compensation" Law, 80 HaRv. L. REV. 1165 (1967). 
bargaining than they did before unionization. These workers may not currently be willing to leave the union because their alternative sources of employment may be still less attractive: The restrictive practices of unions may make it difficult to find employment elsewhere within the industry and the aggrieved employees may be unable to transfer their acquired skills and contracts-their specific human capital-to a new line of work. It is difficult to guess the frequency with which this might happen, but as to the possibility there can be no doubt; the labor cases make it clear that the existing contract rights of workers do not survive the institution of collective bargaining. ${ }^{139}$

Let us suppose, however, that we can get over the baseline difficulty. There remains the problem of distributing the surplus. In the classical eminent domain situation, the surplus takes the form of a public good which by virtue of its non-exclusive nature is necessarily shared by the individuals taxed or otherwise charged with the cost of the taking. The subsequent distribution by the state is therefore unproblematic. ${ }^{140}$ Unionization, by contrast, creates no nonappropriable public good, but only a complex network of institutions to distribute the cash or in-kind benefits to its members. As to the distribution of this surplus, the theory of eminent domain provides no clue.

The implications should be clear. Within the framework of individual rights, it is proper to accept Hobbes's injunction that the determinants of contractual fairness lie in the "appetites of the contracting parties." No one need undertake the impossible task of forming a theory of substantive justice in exchange, sufficient to cover all exchanges. The complex structures under the labor statute increase the need for a substantive theory but decrease the likelihood of finding it. State-protected unions mirror the problems of collective governance in the larger political context. While the political process is governed by an elaborate constitutional mechanism designed to curtail the excesses of majoritarianism with a finely honed catalogue of individual rights and limitations on state power, collective bargaining does not confront the parallel issues of public governance that it raises. To quarrel with how courts resolve individual cases is, again, to miss the central point. Their "deference" in these matters can be traced not only to a basic sympathy to the underlying Act, but also to the impossibility of developing a coherent theory of fairness for collective choice

139. See supra note 118 .

140. The original insight that the regulation should leave those who are burdened by it better off in the long run than they were before dates from Michelman, supra note 138, at 1214-24. For my own reformulation of the position, see Epstein, supra note 14. For its application in the private law context, see Epstein, Nuisance Law: Corrective Justice and its Utilitarian Constraints, 8 J. LEGAL STUD. 49 (1979). 
within the union context sufficiently powerful to override union determinations to the contrary.

The basic structure of the Wagner Act also precludes its effective justification on utilitarian grounds. As any surplus (or deficit) obtained by the union is not uniquely appropriated, the statute has in effect created a "common pool" of assets for members of the union, with the well-known attendant difficulties. ${ }^{141}$ Resources are dissipated, if not by overfishing, then by political action undertaken to increase shares while simultaneously shrinking the total size. The battle will often be intense because a union protected by government order will be able to appropriate economic rents from firm-specific resources ${ }^{142}$ and perhaps monopoly profits from industry-wide cartelization. Any worker who leaves the union will not be able to share in those profits. For this reason, the "exit" rights that are so important, for example, in disciplining capital markets, are far less reliable in the labor context, as workers are reluctant to shift jobs and abandon their share of the collective surplus. To avoid these problems, sensible legislation removes resources from common pools. The labor statutes place them there.

The conflicts brought on by the New Deal legislation also send out false signals to other product and labor markets. Thus where the union collapses the wage differential between skilled and unskilled workers, it reduces the incentives for individual workers to acquire those skills. Likewise, the presentation to the employer of a wage scale that does not accurately reflect the marginal levels of productivity will lead him at the margin to substitute, for example, capital improvements for high-priced unskilled workers. ${ }^{143}$ The ultimate consequences of these distortions are beyond the power of lawyers (and perhaps economists) to measure, but there is no reason to believe that on balance they bring about an increase in levels of output, be it by worker or firm, industry or nation. The declining success of heavily unionized industries-steel, textiles, automobiles-is not some unfortunate coincidence unrelated to the central structures of American labor law. It is far more likely that it is the necessary outgrowth of a system that shrinks the pie for the benefit of those workers (typically those employees protected by seniority) and those offi-

141. See generally Sweeney, Tollison \& Willett, Market Failure, the Common-Pool Problem, and Ocean Resource Exploitation, 17 J.L. \& ECON. 179 (1974).

142. See the earlier discussion on the same point for yellow dog contracts, supra pp. 1370-75.

143. The distributional questions within unions are also relevant to one possible explanation of union behavior, which is that unions have to prevent outsiders from freeloading upon the wage scales that they develop at positive cost in their negotiations with employees. Assuming this concern to be valid, the union can control for the issue by trying to limit the circulation of the scale, which may in fact be very difficult to do. Nonetheless it is doubtful that any employer would want to rely upon the union differentials in setting his own standards because the internal union conflicts make it a very bad measuring rod for wage differentials in a nonunion setting where these problems are less acute. 
cials who gain from the short-term maintenance of a supra-competitive wage structure.

\section{The New Deal in Context}

Having looked at its basic structure, we are now in a position to evaluate the Wagner Act in its relationship to the New Deal and the rise of the administrative state. The central theme concerns the relationship between substantive rules and the administrative structures that are necessary to enforce them. The simpler the rules, the easier it is to implement them by ordinary common law procedures; in part the simplicity of the common law rules, and their substance, are a reflection of the administrative limitations of courts. A collective rule that recognizes the individual right to exclude others from the property one owns, for example, transfers the balancing of interests to private parties, leaving the role of the state to enforce the private determinations so made. A rule that requires balancing of two types of rights-private property and rights of organization under Section 7, for example-demands a far greater level of public supervision. There is little need for the NLRB under a sensible version of common law rules, for the one thing that courts know well is the law of contract, property, and torts. And as we have seen, from these simple tools, one could fashion virtually all of the rules of labor relations. The labor statute, in contrast, breeds a need for administrative expertise. If ordinary judges cannot be expected to understand the intricacies of the tax code, how can they be expected to do better under the labor code? The need for administrative control is also critically shaped by the substantive rights and duties created under the statute. What court could determine the boundaries of a proper bargaining unit? And what court could supervise an election to see that it is not conducted in an "unfair" manner, as that term is defined by the statute? There are too many possibilities and too many parties to handle the question in ordinary litigation. Indeed, as there is no obvious plaintiff or defendant, adversary litigation will not do. We have no system of rights but an elaborate balancing of interests that invites and lends justification to the administrative process.

The same theme emerges from the structure of the unfair labor practices. As virtually every labor disagreement becomes the source of a possible legal dispute, it is very difficult to place upon the courts the enormous burden of sifting through these cases. An administrative board to relieve the stress gains an obvious sort of appeal, if only as a filter for unmeritorious claims. In the same vein, the remedial aspirations of the labor statutes are far greater than those of the common law. The common law spared itself massive complications when it enforced contracts at will. Within the administrative framework, damages and injunctions are only part of the 
picture. There are also elaborate rules for reinstatement of individual workers and complex rules for post hoc changes in union elections that go beyond the powers of courts of equity, which balked at any form of specific performance in labor contracts. The basic structure of the Wagner Act thus forges a powerful commitment to an administrative government to which courts will be required to give great deference.

Why should anyone want to adopt this structure? We are told that it is done in the name of industrial peace and industrial democracy. As regards the first we can assume the end is a good, but question whether the statute is the means to achieve it. Mandatory bargaining by exclusive representatives increases the likelihood of bilateral monopolies that reduce the likelihood of agreement. ${ }^{144}$

There remains the question of violence. In principle the response should be clear: Violence should be punished no matter who is responsible. But it is mistaken to ignore the heavy social costs that may be associated with its suppression, especially if there is widespread political support for those who have committed it. Here, therefore, it may be suggested that the purpose of the statute is to defuse violence that might otherwise occur by offering some improved chances of unionization. Yet support for the statute on this ground is itself fraught with peril. It is simply a pragmatic argument which says that sometimes it is better to surrender to the threat of illegal force than it is to resist it. What is lost is any prudential argument that these structures ought to be preserved as of right even in a world without violence. It therefore becomes a purely tactical question of whether the rest of society is better off with the adoption of the New Deal labor legislation or with the punishment of violence when it occurs.

Indeed, those prudential grounds could be used in ways inimical to the legitimate interests of unions. What, for example, could be said against those who support making unions illegal (as criminal conspiracies no less) on the ground that they are a breeding ground for violence which can only be controlled by powerful and draconian measures? One answer rests on the empirical assertion that these measures will be overbroad, but a complete answer must recognize that overbreadth exists only in relationship to some permitted end, which in turn rests upon some prior and independent conception of entitlement. That point in turn depends upon the further acceptance of the proposition (skirting the antitrust difficulty) that the voluntary combined activities of workers for their common good are themselves lawful if pursued by proper means. But it is this same independent sense of entitlement that supports the case of the employer to control the use and operation of his business by the same means, even when faced by

144. See supra p. 1396. 
the threat of violence. To leap too quickly to the question of social costs is to ignore the question of entitlements altogether. To protect voluntary associations from violence from without, however, is itself a neutral principle that should be applied to both unions and employers.

An analogy to the issue of freedom of speech is appropriate. In certain cases it is said that speakers should not be allowed to air their views because others may respond with violence. Yet the general answer is that no one should (save in very extreme situations) be allowed to suppress the rights of another by committing or threatening a wrong. The speech should be protected and the violence punished or prevented if or when it occurs. If anticipatory measures are needed, they should be narrowly tailored to the evil at hand. ${ }^{\mathbf{1 4 5}}$

Another analogy comes from the law of self-defense. There, a defendant who does not use excessive force may inflict harm upon a plaintiff that exceeds the harm which he expects to suffer-again on the principle that those in the right need not yield as a matter of course to those in the wrong. These same principles can be extended to labor disputes. If an employer wants to employ only non-union labor, his right (and it is a right) should be abridged only as a last resort when those opposed to his decision might take to the streets. There are, of course, problems in the administration of justice and in the control of the police, but initially these are best handled by direct reform of criminal and safety procedures and not by the introduction of an elaborate scheme of labor relations illtailored to the evil to be avoided.

It is also said that participation in democracy is essential to industrial stability. Here again the implicit analogy is to the general structure of government which in this country rightly takes democratic lines. The analogy is nonetheless flawed. The basic problem in general political theory is the question of political obligation: Why is it that any individual owes obedience to the commands of the state? Since Locke, the extensive efforts to account for the state have frequently appealed to notions of consent, however attenuated. The argument against this line is that the attenuated forms are often or wholly fictional, so that the obligation to the state in the end rests upon an uneasy mixture of consent and necessity: Given any vision of individual rights, some limited form of collective control is better than the anarchy that it replaces. By this version, democracy is required because voluntary transactions, however numerous and complex, fail to generate a single group of individuals vested with a monopoly of force within the jurisdiction. ${ }^{146}$ Yet in the labor context, voluntary agree-

145. On picketing, see supra p. 1376-79.

146. Indeed, it is the inability by voluntary agreement for a single protective association to obtain a monopoly of force within a jurisdiction which explains why libertarian accounts of a state as a 
ments by contract are a perfectly viable mechanism for social organization: The state with its monopoly of force is already in place. In the political context, we appeal to democracy because the building blocks of contract, property, and tort fail, singly and in combination, to account for any monopoly of force within the jurisdiction. Yet once the basic political order is assured, there is no reason to take the second-best alternative in labor relations when the best is still available. Those workers who want to form voluntary organizations should be allowed to do so. It is not part of a tradition of voluntarism or democracy to grant workers the power to conscript the employer and dissenting workers into the service of their cause.

It may be said that workers will be alienated from their jobs without the protection of the union. This argument cannot explain the fraction of workers who would rather deal with the employer directly. In no event can it justify the basic structural decision of the Wagner Act that forbids employers to negotiate contracts of employment directly with workers without union intercession, even with regard to their individual grievances under the collective agreement. ${ }^{147}$ To repeat the central point, an argument against the Norris-LaGuardia Act and the Wagner Act is not an argument against unions as such. It is an argument against the special privileges and immunities that these statutes confer upon them. Where unions are necessary to foster communication, they can emerge in any voluntary situation, in a form less formal and less adversarial than it is today. The frequently cited goals of labor organization do not justify the essential features of the modern law.

Calvert Magruder wrote of the Wagner Act shortly after its passage:

We seem to be moving slowly toward a more rational relationship between capital and labor. For the greater part of the past half century, the law tended, on the whole, to retard this consummation. In the latter years its influence, decisively, has been in the right direction. Such progress as we have made has been at needless cost of blood and tears, and economic wastage. If employers would accept with right good will the principles of the National Labor Relations Act, as the carriers generally have accepted its sister Act, it would mean: Away with yellow dogs, company unions, blacklists, deputy sheriffs in the pay of employers, barricades, tear gas, machine guns,

purely voluntary organization must fail. For an effort to overcome the difficulty by positing a set of "visible hand" explanations, see R. Nozick, supra note 29, at 10-25. These explanations do not, however, eliminate the need to develop a good theory of forced exchanges.

147. See Vaca v. Sipes, 386 U.S. 171 (1967) (good faith judgment of a union not to take an individual claim to arbitration does not violate duty of fair representation); Feller, $A$ General Theory of the Collective Bargaining Agreement, 61 CALif. L. REV. 663 (1973); Summers, The Individual Employee's Rights Under the Collective Agreement: What Constitutes Fair Representation, 126 U. PA. L. REV. 251 (1977). 
vigilante outrages, espionage, and all that miserable brood of unionsmashing detective agencies. Can anyone doubt the cordial response labor would make to such a gesture? The old ways will not work, could not work, really. It is time for an act of faith. ${ }^{148}$

No one can quarrel with the power of Magruder's prose. The strength of his arguments, both positive and normative, is quite another matter. In particular, there is no theory of behavior which can explain why labor will give a "cordial" response under the labor acts. While a theory of individual self-interest may not unlock all the secrets of family behavior or religious belief, it is by far the best predictor of behavior between strangers in an economic setting. That theory predicts that unions and their members (like employers) will press for their maximum advantage after the passage of the Act as well as before. There is a theory of "sunk benefits" as well as a theory of sunk costs. That theory of self-interest predicts that unions will never make voluntary concessions tomorrow because of an indefeasible benefit they have received today. On the normative level, too, Magruder's list of grievances against the old order is fatally flawed because of his willingness to condemn contractual practices such as the yellow dog contract and the company union in the same breath that he condemns the use of force in all its manifestations. And he never asks the hard question whether the use of force by employers was justified by the threats of violence by workers. ${ }^{140}$

The course of labor relations under the New Deal statutes has been far rockier and more complex than Magruder foresaw. Unions (except those in the public sector, where their monopoly power is greatest) have continued to lose ground notwithstanding their special legal advantages, a phenomenon best explained by the simple observation that they do not provide their membership with benefits that exceed their costs. It is also fair to say that the intellectual difficulties with the statutes have been far greater than Magruder realized, or could have realized. Increasing disenchantment with organized labor in this country is now a force to be reckoned with in the political arena. Much of that concern is with personalities and the subject matter of particular disputes. What is needed is a greater concern with the institutional structures in which these personali-

148. Magruder, supra note 3 , at 117 .

149. Compare F. FRANKFURTER \& N. GREENE, supra note 3, at 132-33 with Petro, supra note 69 , at 429, 434-35, 446-70. In my view Petro has much the better of the historical argument. The chief flaw of the Frankfurter and Greene study is, as Petro points out, that it never asks the question of whether the issuance of the labor injunction was a use or an abuse of power. Where there is the threat of force by workers, it is the failure to grant the injunction that is the abuse of discretion, not its issuance. Petro, supra note 69 , at 436 . And as Petro rightly points out, id. at $377-83$, the application of the injunction to labor cases did not involve any departure from the well established equitable principle that injunctions are an appropriate response to threats of irreparable harm. 
ties operate and these disputes take place. At present, there may be little prospect for the repeal of basic labor legislation, and there is none for its constitutional overthrow. The possibilities of incremental changes, however, are always present, and the opportunity for a major rehauling might even follow an intensive reexamination of the subject. The New Deal brought forth major labor law legislation, but as a normative and intellectual matter it did not conclude the debate on the nature and function of labor law. 